\title{
Dagbogsnotater fra det sidste krigsår 1944-45
}

\section{Af Poul Andersen}

I Sønderjyske Årbøger 1978 fortalte Poul Andersen om sine ni år på Søgård ved Højer, som han forlod den 1. maj 1944 for at overtage Nørmark ved Visby. Arbejdet på den nye gård blev brat afbrudt den 5. september 1944, således som der fortælles nedenfor $\mathrm{i}$ dagbogen. Redaktionen har gerne optaget dette bidrag, der tjener til at belyse opfattelser og følelser hos én af dem, der ikke blev underkastet besættelsestidens allerhårdeste vilkår.

Først et par ord om dagbogen. Den måned, jeg tilbragte $\mathrm{i}$ arresten på domhuset i Kolding, blev notaterne gjort på indpakningspapir, som jeg fik smuglet med ud, da jeg blev sendt til Frøslev.

Gennem en dansk fængselsbetjent fik jeg i Frøslev en lille lommebog, $9 \times 16 \mathrm{~cm}$, og i denne overførte jeg det, jeg havde skrevet $i$ Kolding, og førte så dagbogen videre til 24. april 1945. Tillige med ca. 400 andre skulle jeg den 25. april overføres til Sverige med tog fra Padborg.

Det afsnit, der omhandler tiden fra 25 . april til kapitulationen, er nedskrevet de første dage i maj.

Der er i dagbogen udeladt notater af så privat karakter, at de kun kan have interesse for mine pårørende.

Under opholdet i Frøslev havde vi det materielt godt; men en indespærring - frihedsberøvelse - var og blev det, og som et stadigt tryk over hverdagen lå tanken om, at man kunne komme med på næste transport til en KZlejr i Tyskland.

Inden dagbogen får ordet, skal nævnes, at jeg i februar havde solgt Søgård ved Højer og 1. maj havde overtaget og var flyttet ind på Nørmark ved Visby. Den 26. maj blev en række folk i Sønderjyllands administration arresteret. I Tønder drejede det sig om politimester Brix og kaptajn P. M. Digmann. I Gråsten ville man også arrestere oberst S. Paludan-Müller, chefen for Grænsegendarmeriet. Hans kamp ene mod overmagten gjorde et dybt indtryk på den sønderjyske befolkning.

Af listen over de arresterede kunne jeg se, at det varfolk med tilknytning til den såkaldte P-ordning, der var taget. Selv om jeg kun var beskedent involveret heri, spekulerede jeg på, om der nu også kom bud efter mig, men intet skete. Så ganske uventet slog lynet ned.

Den 5. september 1944 kom Gestapo: 
194

Poul Andersen

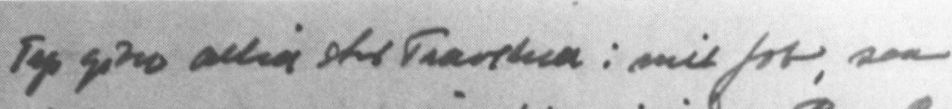

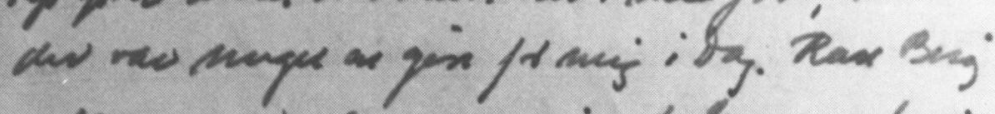

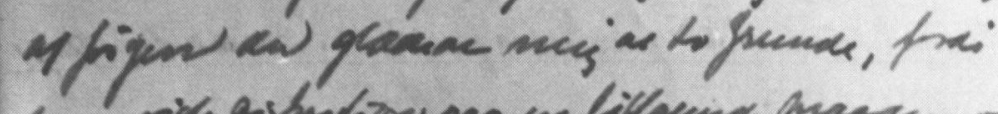

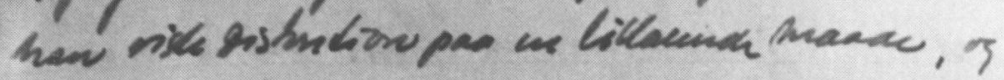

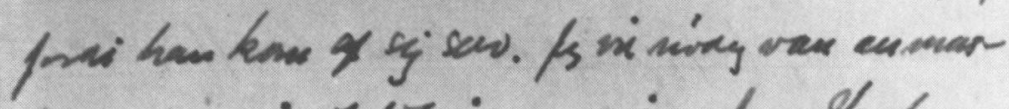

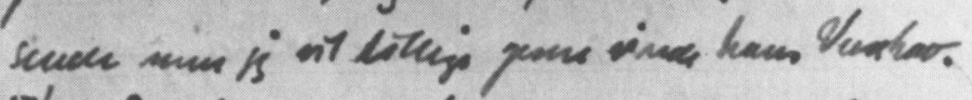

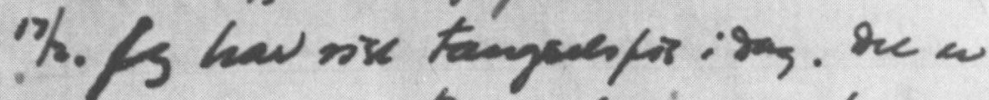

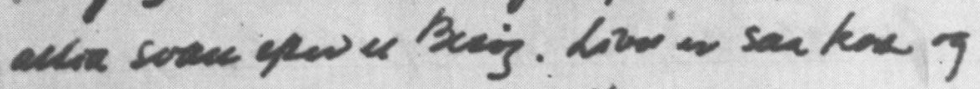

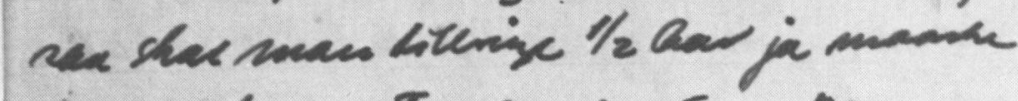

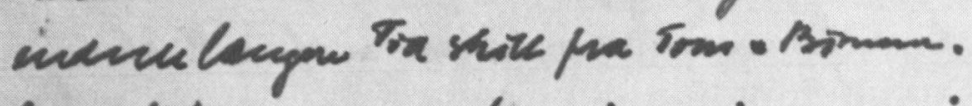

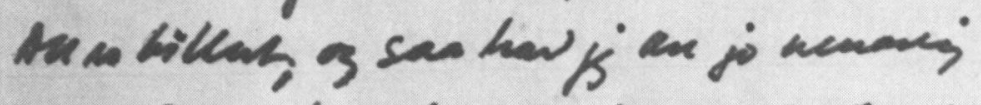

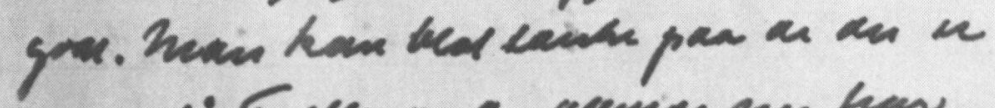

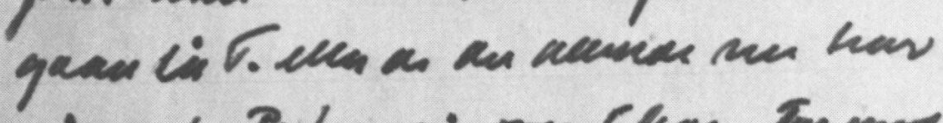

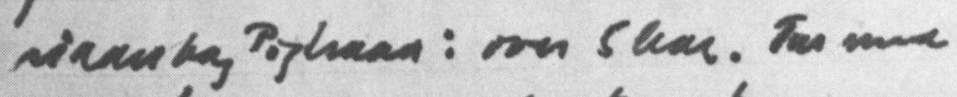

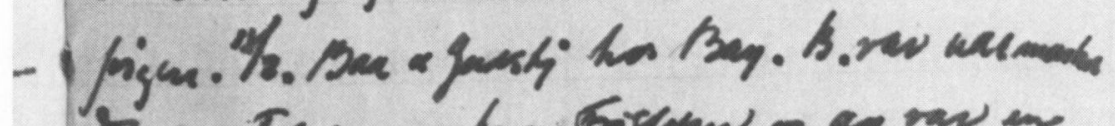

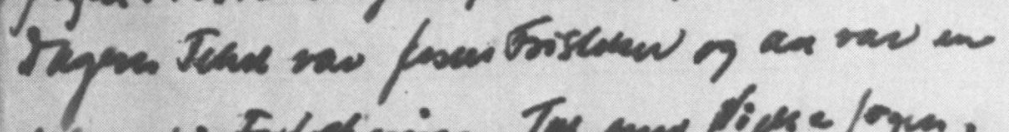

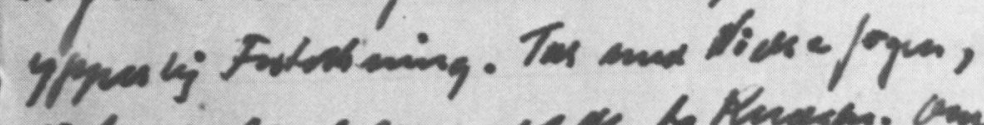

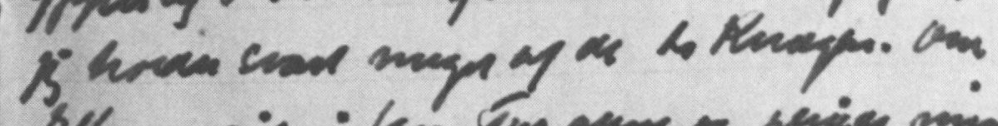

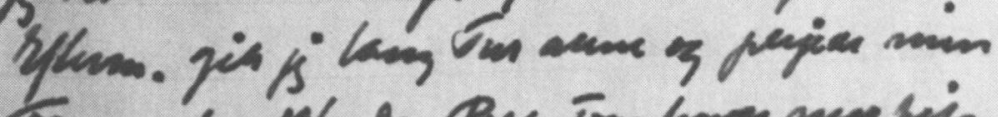

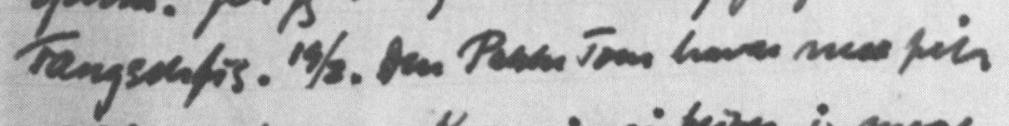

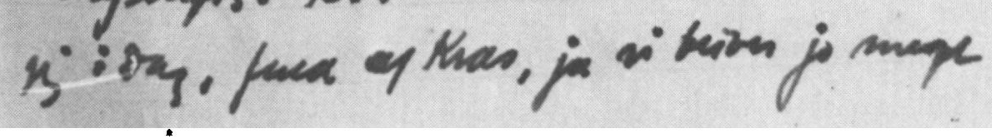
Dagbogsside, der ikke er medtaget i artiklen. 
5.9. Det havde regnet om natten, så kornet var for vådt til at køre ind. Jeg gik en runde over markerne. En af karlene pløjede stubbe, de andre var i gang med at skokke korn om. Da jeg kom hjem fra marken, kom dyrlæge Westermann, der skulle se på en syg so. Efter at han havde stillet diagnosen, gik vi ind for at telefonere efter medicin. Mens vi stod ved telefonen, så vi en benzindreven bil svinge ind ad indkørselen. "Hvad kan det være for en vogn?" sagde jeg. "Det er nok Gestapo", svarede dyrlægen. "Ja, det er det nok, « replicerede jeg i spøg, lidet anende, at det var bitter alvor.

Jeg gik ud i forstuen for at se, hvilke gæster der kom til gården, og så stod de der allerede, tre mand høj, og pegede overbevisende på mig med deres pistoler.

Jeg vil ikke nægte, at det generede mig, og da de præsenterede sig som det tyske sikkerhedspoliti, slog det ned i mig: "Så er det sivet ud om vort lager af sprængstof på Søgård.“

De to af de tre var tyskere, den tredie en såkaldt dansker. De spurgte straks, hvor jeg havde mine våben, og da jeg benægtede at have våben, bad de mig følge med til en kort afhøring på ortskommandanturen i Tønder. Det skulle kun vare nogle timer.

Nå, jeg fik lov at klæde mig om, ganske vist under behørigt opsyn, om det så var på toilettet fulgte der en med. Tom ${ }^{1}$ og ungerne trippede omkring mig, og det var det værste at skulle se på dem. Ja ungerne forstod ikke alvoren. Tom var ikke glad, men hun tog det i stiv arm, Gestapo skulle ikke se, at vi krøb.

Da jeg nu havde beskikket mit hus og sagt farvel, og vi gik gennem forstuen, havde postbudet lige været der og lagt dagens post.

Den danske medhjælper sagde så: "De må hellere lige åbne Deres post.“ Imidlertid havde jeg set, at der blandt brevene var eet, der indeholdt illegale blade, som jeg ugentlig distribuerede, så jeg svarede, at det var såmænd kun regninger, og de kunne roligt ligge de par timer, det ville vare, til jeg var hjemme igen.

Men der var ingen vej uden om, og så åbenbaredes det, at et af brevene indeholdt illegale blade. Det lod til at være en alvorlig sag, i al fald blev det besluttet, at der skulle foretages husundersøgelse. De begyndte i min stue. Skrivebordet blev åbnet, skufferne endevendt. Alle mine papirer vedrørende Det unge Grænseværn, og alt hvad der angik terrainsport blev taget med. Blandt andet var der en meldingsblok med notater om troppebevægelser, som de gjorde et stort nummer ud af.

Nå, ellers syntes jeg undersøgelsen var ret overfladisk, og med lidt behændighed lykkedes det mig at skjule noget. Bøgerne tog de ud af reolen og rystede dem for at se om de indeholdt papirer, og pudsigt nok dukkede der en 
illegal pjece frem, jeg længe havde ledt efter. Den blev selvfølgelig også beslaglagt.

Efter en times tid sagde jeg endnu engang farvel, og så kørte vi ud af gården. Efter at have kørt ca. $500 \mathrm{~m}$ stoppede bilen, og den ene tysker spurgte, om jeg ønskede at blive fri, og da jeg naturligvis bekræftede dette, svarede han, at i så fald skulle jeg blot vise dem, hvor jeg havde mine våben skjult, så ville jeg straks blive løsladt.

$\mathrm{Da}$ jeg atter benægtede, at jeg havde våben, kørte vi videre, men endnu to gange inden Tønder stoppede vi, og tilbuddet om løsladelse gentaget. Da jeg tredie gang nægtede at have våben, blev tyskeren, kriminalrat Wehmann ærgerlig og sagde, at så måtte jeg tage følgerne. Jeg spekulerede noget på, om de virkelig var så naive at tro, at nogen anholdt ville hoppe på den limpind om løsladelse.

Da vi kom til Tønder, skulle vi have noget at spise. Jeg foreslog hotel Tønder, men mine værter foretrak Deutsches Haus, og derved blev det. Mens vi spiste, bad jeg om lov til at telefonere til en af mine gamle karle for at bede ham hjælpe med høstarbejdet på Nørmark, idet jeg så ville ringe til Kjeld Posselt og på denne måde advare ham. Vi var i gruppe sammen. Vi fik forbindelsen til Posselt, og jeg indledte med at sige, at jeg var arresteret af Gestapo, hvilket danskeren, der overvågede samtalen, sagde, at det måtte jeg ikke sige, men da var det sagt.

Vi fik stegte kartofler og spejlæg, men jeg var ikke mere gæst, end jeg selv måtte betale for min portion.

Under måltidet spurgte danskeren, om jeg ikke kendte ham? Jeg svarede, at det næppe var tilfældet, men så hævdede han, vi tit havde spillet fodbold sammen i vore drengeår, og så kunne jeg placere ham og vidste, at han tillige med tre brødre var gå et $i$ tyskernes sold, og videre samtale mellem os ophørte.

Fra Deutsches Haus blev jeg kørt ud til Tønder kaserne og der indsat $\mathrm{i}$ arresten, hvor jeg kunne spekulere over min videre skæbne, mens de tre herrer kørte videre. En venlig tysk vagtmester kom med en stor portion gule ærter, som jeg dog ikke kunne spise. Kl. 19 vendte de tre Gestapofolk tilbage, og jeg blev ført ud til bilen, og så gik det i fuld fart over Åbenrå til Kolding. Ved 21 tiden holdt vi foran domhuset i Kolding, og under skarp bevogtning blev jeg ført op til celle nr. 6. Døren låset op, og jeg blev skubbet ind.

6.9. Jeg sov godt om natten trods dagens mange indtryk og alle de tanker, jeg gjorde mig om fremtiden. Vi er fire mand i cellen, to politiske fanger og to sortbørsgrosserere. De sidste er arresteret af feltgendarmeriet, taget på fersk gerning under udførelse af deres smarte forretninger.

Cellen, der ligger på tredie sal, er $4 \times 2,5 \mathrm{~m}$, så der er ikke megen plads at 
røre sig på for os fire beboere. Vinduet, der er forsynet med et kraftigt gitter, sidder så højt, at man må op at stå på briksen eller skuldrene af en cellekammerat for at se ud. Det første, mine cellekammerater spurgte om, var, om jeg havde tobak, de var nemlig udgået for denne vare, så da jeg tog en pakke Powhattan frem, blev der stor jubel. Vi fik tændt en cigaret, og præsentationen begyndte. I begyndelsen var vi jo lidt forbeholdne, man skulle nødig være dumpet $i$ kløerne på en stikker. Men det viste sig ret hurtigt, at der kunne tales frit, og så skulle jeg som den nye orienteres.

Dagen begyndte 5.30, så blev vi vækket, fik lov at gå på W.C., og cellen skulle rengøres. Vore to madrasser stables ovenpå hinanden, det ene lagen og de tre tæpper, vi havde til deling, lægges sammen, gulvet fejes og hveranden dag vaskes, og cellen var så ændret fra sovekammer til dagligstue. Selv skulle vi vaskes og barberes. Barbermaskinen blev udleveret af den tyske vagtpost hver morgen og skulle afleveres efter brugen, derimod kunne man godt beholde barberbladene, så hvad meningen var med denne aflevering, var det ikke let at blive klog på. Tysk reglement er af og til besynderligt. Kl. 7 serveredes morgenmaden, som bestod af noget, der blev betegnet som kaffe. Det var en varm, brun drik. Til dette fik man to humpler rugbrød og hveranden dag en klat smør på ca. 10 gram. Jeg havde travlt med at få tips om forhør og var ærlig talt ikke helt stolt ved situationen, da jeg ikke vidste, hvor meget Gestapo vidste.

Ved 9 tiden begynder klokkerne at ringe gennem bygningen. Én gang er den danske afdeling. To gange er Gestapo og tre gange er feltgendarmeriet. $\mathrm{Kl}$. godt 9 ringer det to gange. Gestapo kommer for at hente gårdsdagens fangst, og jeg bliver hentet ud af cellen og sammen med tre andre puttet ind $i$ en bil og hurtigt kørt gennem Koldings gader til Staldgå rden, hvor Gestapo har sit hovedkvarter. Her bliver vi sat ind $i$ celler, der kun er vægge, loft og gulv, svagt oplyst af en lille elektrisk pære i loftet. Atter ventetid, og så bliver jeg fert til forhør hos kriminalrat Wehmann. Han var korrekt, da han modtog mig i et stort lyst kontor, hvor der foruden os var en dansk maskinskrivningsdame. Wehmann begyndte med at spørge, om jeg kunne klare et forhør uden tolk, og da jeg bekræfter dette, begynder han efter en meget alvorlig henstilling om "sagen nur die Wahrheit.«

Først måtte jeg redegøre for fødsel, familie, bopæl, erhverv o.s.v. Det tog sin tid, da alt skal nedskrives på maskine, og det havde nok været en fordel, om hr. Wehmann havde taget et kursus i maskinskrivning. Så begyndte vi at tale om terrainsport, og han hævdede, at alle der beskæftigede sig med terrainsport var sabotører. Jeg svarede, at så måtte jeg være en undtagelse, for jeg var ikke sabotør. Det ville han heller ikke påstå, men var jeg det ikke, så havde jeg i al fald oplært unge til det. Også dette benægtede jeg, og jeg 
kunne oven i købet gøre det med en god samvittighed. Det talte vi så meget om, og Wehmanns omkvæd er bestandig: "Sagen nur die Wahrheit, Herr Andersen."

Jeg drager et lettelsens suk, da vi efter fire timer har talt om terrainsport og dennes opdragende betydning for dansk ungdom, hvor skammeligt det var, at vi ikke havde et ordentligt forsvar i Danmark og meget mere af samme skuffe, uden at vi egentlig kom ind på noget konkret om mine forhold. Jeg blev så igen sendt hen i cellen, hvorfra jeg en time senere blev kørt tilbage til domhuset, efter at jeg var blevet kropsvisiteret og berøvet alt, også en neglerenser af træ, mit ur og mine penge.

Jeg gik nu ud fra, at jeg var arresteret, fordi jeg havde beskæftiget mig med terrainsport. Det er et svineheld.

Tilbage $\mathrm{i}$ cellen går dagen med snak og læsning. Mit nye testamente havde jeg ved visiteringen fảet lov at beholde, og det er betydelig mere lødig læsning end de kulørte hæfter, cellens bibliotek iøvrigt råder over.

Jeg fik ingen middag idag, den var serveret, mens jeg var på Staldgården, men kl. $17 \mathrm{kom}$ aftensmaden. Den består af samme drik som om morgenen og hertil fire tørre skiver rugbrød og en skive pølse. Kl. 21 slukkes lyset $i$ cellerne. Forinden skal fodtøjet stilles ud på gangen. Ikke for at blive pudset, som på et andet hotel, men så er vi nødt til at flygte i strømpesokker, hvis vi ellers kan få tremmerne foran vinduet savet over og tor springe ud fra tredie sal.

7.9. Ny dag begynder. Mine medfanger fortæller, at jeg næppe kommer til forhør idag. K1. $9.30 \mathrm{er}$ der gårdtur på 25 minutter. Det er den første friske luft, jeg får efter min arrestation, og jeg nyder det. Jeg sætter mig i en solvarm krog i gården. Tankerne går hjem. Det gør de uophørligt. De 25 minutter er snart forbi, og så skal man atter låses inde. Det er en modbydelig lyd af de raslende nøgler, og ækelt, at der ikke er noget håndtag indvendig på døren.

Kl. 12 kommer middagen. Idag nudler $i$ en slags vælling, serveret $i$ en blikskål, så nu har jeg også spist af bliktallerken.

Efter middag er der postuddeling. Jeg har skrevet hjem, det kan der endnu ikke være svar på, men der er en pakke med mine barbersager og en kærlig hilsen derhjemme fra.

Resten af dagen går med at løse kryds og tværs,og jeg forsøger af lære mine medfanger at spille bridge, og så ryger vi vort sidste lommeuld.

Kl. 21 slukkes lyset, men sove på den tid er ikke let. Tankerne myldrer frem og tilbage. Hvordan går det derhjemme på Nørmark. Krigen er ikke forbi, selv om de allierede maser godt på gennem Frankrig. Et rygte vil vide, at de nærmer sig Køln, så må tyskerne da snart indse, at det er slut. 


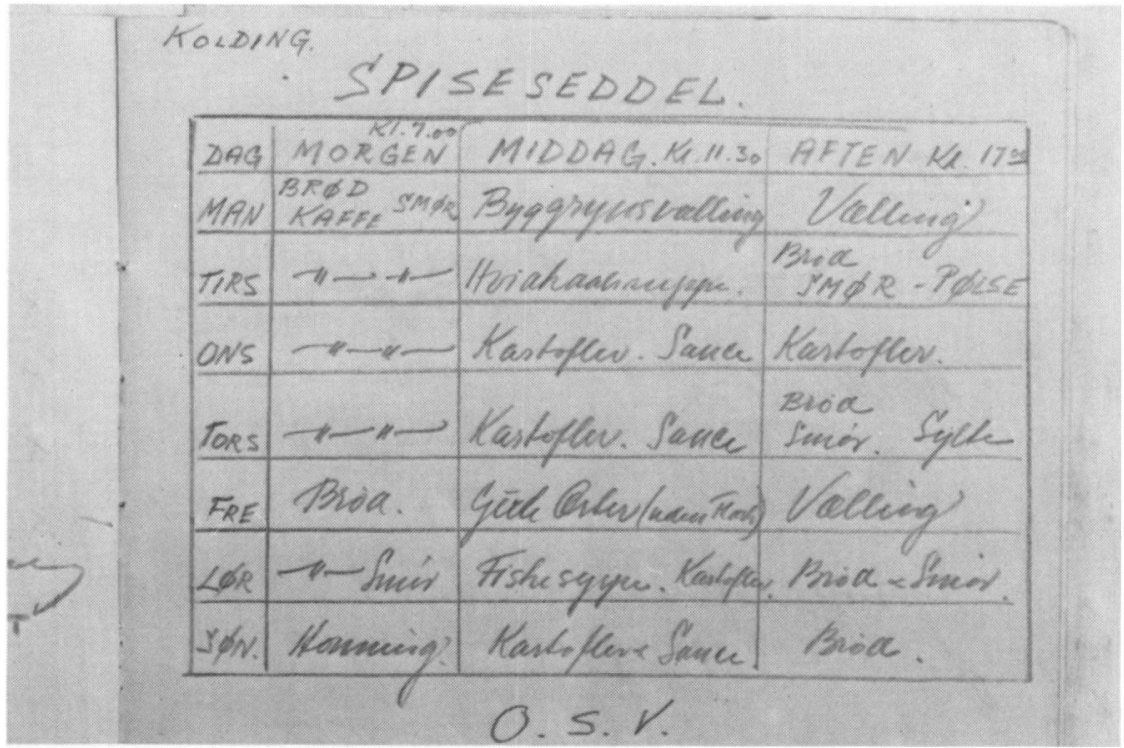

Ugekostplan fra domhuset i Kolding. Spandende var den ikke og uandret uge efter uge.

8.9. Idag blev jeg atter hentet til forhør. Wehmann modtog mig med et: "Wir wollen uns ein bischen unterhalten, aber nur die Wahrheit.« Idag var det ikke terrainsport, men om Søgård,spionage. Man havde set lyssignaler til engelske maskiner, når der var natlige overflyvninger. $\mathrm{Og}$ jeg havde jo engelske sympatier. Det havde jeg givet udtryk for på en jagt, hvor der havde været medlemmer af mindretallet til stede. Wehmann kunne også nævne hvilke dage "Danmarks Ole «" og Carl Bartholdy ${ }^{3}$ havde aflagt besøg på Søgård, og de var begge internerede for deres tyskfjendtlige optræden. Han mente, jeg godt kunne indrømme, at jeg var spion.

Forhøret var skredet frem under ret vanlige former, men så slog han pludselig om. Først tog han under meget spektakel en revolver frem og lagde den demonstrativt på bordet, lidt senere en fladtang, legede med den, bankede sig på neglene med den, idet han sagde: "Also hr. Andersen, sagen nur die Wahrheit. Wir sind nicht G.P.U., aber wir haben anderen Methoden.“ På hans skrivebord lå et brev, hvor jeg på udskriften kendte Toms faste skrift. Af dette brev fremtog han nu nogle billeder af hende og børnene. Så længe på dem, og sagde så "Det er jo en smuk familie, De vil vel gerne hjem igen, så nu må De rykke ud med sandheden."

Vi kom ikke videre. Jeg nægtede at være spion. Sabotage, det punkt, hvor min samvittighed måske kunne siges at være lidt anløben, kom vi ikke ind på. 
Jeg regnede med at have klaret frisag. Skrev rapporten under og blev atter kørt tilbage til domhuset.

9.9. Midt på formiddagen blev celledøren åbnet af vor gode ven Alfons, en af vore vogtere, der tydeligt havde vist, at han sympatiserede med os $i$ cellerne. Alfons smed en lille pakke ind med mit navn på.

Pakken indeholdt en pakke tobak og cigaretter. Det kan nok være, der blev jubel i celle 6 . Jeg ved ikke, hvem den ukendte giver var, men han eller hun fik mange venlige tanker.

Lørdag er brusedag. Tre ad gangen bliver vi ført til bad. Det er dejligt at få lopperne druknet. Der bor en større koloni i madrasserne, og de plager os en del.

Jeg savner umådeligt at være ude i den friske luft, arbejde legemligt, men først og sidst at være en fri mand. Man skal sikkert have prøvet frihedsberøvelse for rigtig at forstå den.

Vore to sortbørsgrosserere indviede os i forretningens fiduser. De havde begge været ansat på et pakhus på en nordjydsk station, hvortil der ankom tog fra det tredie rige med pigtråd, byggematerialer, søm og lignende varer, som der er stor mangel på i dagens Danmark.

Deres arbejde var at losse vognene ind i pakhuset. Dagen efter sendte de bud efter nogle lastbiler, hvorpå varerne blev læsset. Lastbilerne kørte ikke tingene ud til vestkysten til bygning af den tyske forsvarslinie, men de blev fordelt til forskellige "grosserere".

Man kan naturligvis sympatisere med den tanke, at varerne blev unddraget den tyske forsvarsopbygning eller forsinkede den. Men helt så idealistisk, som de gerne ville fremstille sagen og betragte sig som sabotører, havde jeg dog svært ved. Ikke mindst på grund af, at de tog deres "sabotage“ godt betalt. Men det var en underholdende undervisning i en let måde at tjene penge på - på Nationalbankens bekostning. Og de måtte også indrømme, at det skete, de forgreb sig på andre mangelvarer, der ikke skulle komme tyskerne til gode.

10.9. Søndag. Jeg har hjemve, så det batter. Stod længe på briksen og kiggede ud over fjorden og havnen og ned i haverne, hvor folk nyder fridagen i det dejlige vejr. Solen skinner fra en skyfri himmel, den skinner ind i cellen og tegner et skyggegitter på væggen, som om der ikke var gitter nok i vor nuværende tilværelse.

11.9. Hvilken dejlig dag. Jeg blev kaldt til forhør og var ikke rigtig glad for situationen. Hvad havde man nu fundet ud af. Men da jeg kom op til 
Staldgården, så var det slet ikke forhør, der ventede mig, derimod Tom, der havde fået besøgstilladelse. Hvor var det dejligt - at ses igen. Besøgstilladelsen lød på 20 minutter, der svandt alt for hurtigt, der var så uendelig mange praktiske ting angående Nørmark, vi skulle drøfte. Hun kunne fortælle om gode naboers hjælp og venlighed. Det besøg hjalp på humøret, men svært for os begge at vinke et glad farvel. Og efter besøget var længsel efter familien, gården og friheden ikke mindre.

15.9. Dagene går egentlig forbavsende hurtigt, nøjagtig ens. Morgentoilette. Morgenmad. Læsning og snak. Jeg har megen glæde af Det nye testamente. 10 minutters læsning kan beskæftige tankerne $i$ adskillige timer.

Kabaler $i$ en uendelighed for at tvinge tankerne $i$ andre baner end hjem og de kære der. "Overtroisk « lægger man kabaler. Går de op en gang er der brev, går den op tre gange i træk så er der besøg, men den skal gå op ti gange i træk for at blive løsladt. Den gik op tre gange, og Tom kom på besøg. Den glæde, der er ved at ses og mødes ved disse korte besøg, kan jeg ikke beskrive, derimod at det er modbydeligt at skulle sige farvel.

22.9. Atter idag et besøg af Tom. Det blev på en hel time. Den dansker, der skulle overvåge vor samtale, faldt i søvn, så jeg fik lidt nyheder om krigen, men ellers var det Nørmark og dens problemer, og hvordan det gik i hverdagen derhjemme, der optog mig. Som sædvanlig havde hun en dejlig pakke med. Det kan jo ikke nægtes, at man under de nuværende forhold interesserer sig for materielle goder. Det er et rart supplement til den lidet ophidsende kost pả domhuset.

Da jeg kom tilbage til domhuset, fik jeg ordre til at pakke mine sager, da jeg skulle med en transport. Rygtet lød på Frøslev. Det tyder på, at min sag er afsluttet, hvad forhør angår. Men nogen dom foreligger ikke. En ny a vis, som Tom havde stukket til mig, måtte jeg hurtigst muligt lade forsvinde i W.C. inden visitationen. Jeg havde hurtigt pakket mine få sager $\mathrm{i}$ en pakke, og sammen med 40 ligestillede forlod jeg domhuset. Vi blev proppet ind i en prærievogn, og jeg tor antyde, der var trængsel, og vi var under skarp bevogtning. I forrygende fart gik det gennem gaderne til Kolding banegård. Her holdt vi og ventede en time på toget, der imidlertid ikke ankom, vist på grund af sabotage. Transporten blev udsat og vi kørt tilbage til cellerne.

26.9. Kongens fødselsdag. Fra cellevinduet kunne vi se flagene vaje over Kolding. Da vi var på gårdtur klang »Kong Christian« spontant fra gård til gård. Tyskerne råbte og bandede, men første vers blev sunget til ende, inden vi blev drevet ind. 
Det er slemt at være fire mand så tæt på hinanden alle døgnets 24 timer. Det kan knibe lidt med tolerancen.

27.9. Uventet besøg af Tom. Hun er en knag til at mase på og få besøgstilladelse. Atter idag var besøget 1 time. Hvor jeg dog savner mit hjem og mine kære. Når man er spærret inde, er der en forfærdelig masse tid til at tænke. Vore nærmeste bliver egentlig straffet hårdere. De skal gå i bestandig uvished.

30.9. Så kom idag afrejsen fra dette whotel«. Kl. 18 blev vi samlet ca. 40 mand, der fik ordre til at gøre os rede til afgang. Vi blev stillet op på gangen og visisteret. Mine notater fandt de heldigvis ikke. Under stærk bevogtning ført ned til en åben lastbil, i hvilken vi blev kørt til banegården. Gennemgående hilste folk os med vinken og venlige tilråb, men der var enkelte, der rakte tunge og råbte skældsord. Det er nogle kønne landsmænd.

Da vi kom til banegården, holdt toget der med en fangevogn. Vinduerne er dækket med træ, dog var der et lille hul i pladen på ca. $10 \times 10 \mathrm{~cm}$. Dette hul var dækket med gitter. En vittig sjæl $i$ en tidligere transport havde nedenunder skrevet: "Læn Dem ikke ud." Men lidt lys kom der dog ind gennem hullet, og vi var da også i stand til at se, hvor vi befandt os. Toget kørte langsomt mod syd. Der var mange og lange ophold ved stationerne ned gennem Sønderjylland, så klokken var godt $4 \mathrm{om}$ morgenen, da vi nåede Padborg. Her ventede en større styrke tyske politisoldater på os. Vi blev gjort bekendt med, at ethvert flugtforsøg ville betyde døden. Derefter blev vi stillet op i geledder på 4 mand. På fløjen af hvert geled gik en tysk politisoldat på vor vandring fra Padborg til Frøslev. Politisoldaterne havde åbenbart forkortet ventiden på en kro, de var i al fald noget påvirkede og i fortrinligt humør og fortalte os, at nu kom vi i himlen, for Frøslevlejren var et dejligt sted at være fange.

Efter en halv times spadseretur nåede vi frem til lejren, der ligger i Frøslev plantage. Det var gryende dag, men dog så mørkt, at alle projektører langs pigtrådshegnet var tændt. Ved hovedtåmet blev vi modtaget af den vagtha vende Meister, der på vanlig preussisk maner råbte og skreg. Hvorfor mon tyskere i uniform kun kan råbe? Han førte os over i barak 10, ind i en stue, hvor der var strøet halm på gulvet. Det skulle være vort nattekvarter, oplyste han. Dermed forlod han os og låste døren. Det blev nu ikke til megen søvn, dels var pladsen til at ligge såre beskeden, dels var det koldt, og endelig var vi jo noget spændte på, hvad den nye dag ville bringe.

1.10. Kl. 8 blev vi ført til morgenmad i spisebarakken, og hvilken 
morgenmad i sammenligning med domhusets. Her var havregrød og mælk, så meget vi ville have. Franskbrød og marmelade, det var næsten, som politisoldaterne havde sagt, paradisiske tilstande.

Efter morgenmaden blev vi ført tilbage til barak 10, hvor vi blev grundigt visiteret, inden vi blev sluppet ud i lejren for at orientere os og finde $u d$ af, $i$ hvilken barak vi kunne finde plads hos kendinge.

Jeg blev straks antastet af Bernsen, ${ }^{4}$ som journalist skulle han naturligvis finde ud af, hvem der nu var ankommet til Frøslev. Senere mødte jeg Carl Bartholdy. Der var desværre ingen ledig seng på hans stue, men jeg fandt plads i samme barak, nemlig H.15, stue 11. Det var en 12 mands stue med morsomme og hyggelige mennesker. Rosenkjær ${ }^{5}$ havde boet der, men var deporteret til Tyskland få dage før min ankomst. Udover Bernsen kendte jeg $\mathrm{i}$ forvejen ikke stuens beboere. Mine nærmeste naboer i de toetages køjesenge, vi ligger $i$, er politimester Hebo, Esbjerg, lærer Moustgaard, Lemvig, nervelæge Fuhrmann, Kolding og politikommisær Rasmussen, Esbjerg. Om aftenen er der forrygende diskussioner på stuen. Her er folk fra alle politiske partier. Kommunister og Dansk Samling har vel nok den største repræsentation ikke alene på stuen, men i hele lejren.

Det er krigen, der drøftes, og Danmark efter krigen, men iøvrig kom alle slags emner til debat. Klokken bliver både 1 og 2, inden snakken dør ud.

4.10. Hver morgen er der en ganske kort morgenandagt. Jeg kan godt lide at begynde dagen på den måde. Idag er som straf for et flugtforsøg, der ikke lykkedes, indført brev-, pakke- og besøgsspærring i en måned. Jeg er således afskåret fra at høre hjemmefra $\mathrm{i}$ den periode. Det er lejrens chef, Sturmbannführeren, blandt fanger kaldet Stubba eller storbanditten, der har beordret denne spærring. Jeg må se at få en illegal hilsen hjem. Endnu er jeg ikke sat på noget arbejdshold. Jeg går blot rundt i lejren og får en snak med de mange bekendte, jeg har her blandt de ca. 1.000 fanger. Og det er jo meget hyggeligt, men hele tiden vender tankerne hjem.

5.10. Klokken 5 i morges kom prøjserne trampende ind i barakken, og vi blev kaldt ud til appel på gangen. Det betød en ny deportering til Tyskland. Atter et løftebrud fra tysk side. Man kommer til at tænke på Poul Helgesen, der i Skibbykrøniken siger: "Før vokser figen på hylderod, før tysken vorder dansken god." 190 mand blev udtaget. Det er modbydeligt at overvære. Ved morgenandagten sang vi "Befal du dine veje." Ved transporten var der blevet en plads ledig på stue 3. Det er der Carl og Ole bor, så nu er jeg flyttet derhen.

Mine øvrige stuekammerater er Ohrt, landsretssagfører, Lagergreen, annoncemand ved Berlingeren, Skåning, redaktør i Vejle, Jacob, sergent, 
Holger, korporal, begge i garden. Larsen, sømand og Lyhne, hotelforpagter i Åbenrả. Det er en stue, hvor der er en fin stemning, god moral, og vi har, selv om vi er meget forskellige, samme indstilling til den situation, vi er i.

6.10. Idag kom jeg på arbejde. Blev tildelt et hold, der arbejder uden for lejren på noget vejarbejde i skoven. Det var herligt oktobervejr, og jeg ligefrem nød at få fat på en skovl og få mig brugt legemligt. Men det bedste ved det var, at jeg fik kontakt med en skovfogedaspirant, der sendte et brev hjem til Nørmark. Det er dejligt at vide, at Tom nu får en hilsen fra mig. Det er dejligt at arbejde her i skoven, noget ganske andet end de korte gårdture $\mathrm{i}$ Kolding.

Tempoet bestemmer vi selv. Vore vogtere, de tyske politisoldater, er tilsyneladende ganske ligeglade, om vi slider i det eller hænger på skovlene.

Midt i oktober. Jeg har haft besøg af Tom. Illegalt vel at mærke. Vi havde i nogen tid arbejdet i plantagen uden for lejren med at sætte pigtrådshegn om os selv. Både Bernsen og jeg havde fået sendt bud til vore koner, at vi arbejdede der, og foreslået dem en skovtur. Vi havde faktisk opgivet at se dem. Dels er det jo ikke let at komme hertil, og måske ville det være besynderligt, at netop de lige kom forbi. Men så kom de. Jeg ser Tom på skovvejen og går hen til hende. Vore vogtere, der iøvrigt den dag var tre danske SS, blev så overrumplede over frækheden, at de gav os lov til en lille samtale. Dog skulle vi trække ind blandt granerne for det tilfælde, der kom inspektion. Og det var parodoksalt, at vore vogtere stod på udkig for os. Vi fik 20 minutter. Tom havde mange spørgsmål om Nørmarks drift, så det blev uendelig lidt privat vi fik talt, men dejlig var det at ses, skønt mødet var lidt forjaget. Tom havde også gode forsyninger af tobak og chokolade med, og det kom på et tørt sted, nu der er pakkespærring. Et sådant møde er en rar opmuntring i hverdagen.

Dagene går ligesom $\mathrm{i}$ Kolding forbavsende hurtigt. Håb om løsladelse har jeg skubbet ud $\mathrm{i}$ det uvisse, og alligevel håber jeg hver dag. Det værste ved opholdet her er uvisheden og den trussel, der bestandig hænger over os om deportation til Tyskland. Der er atter gået en transport med et par hundrede gode kammerater mod syd. Det er lige væmmeligt og uhyggeligt at blive kaldt op til appel, når der skal gå en transport. Hvad skæbne går de deporterede ind til?

5.11. Der er atter gået en transport mod syd. Fra vor stue skulle Jacob og Holger med. Det kneb lidt for Jacob. Store, gode, pludrende fyr. Altid et morsomt svar. Han var en humørspreder, som vi vil savne, og så hans 


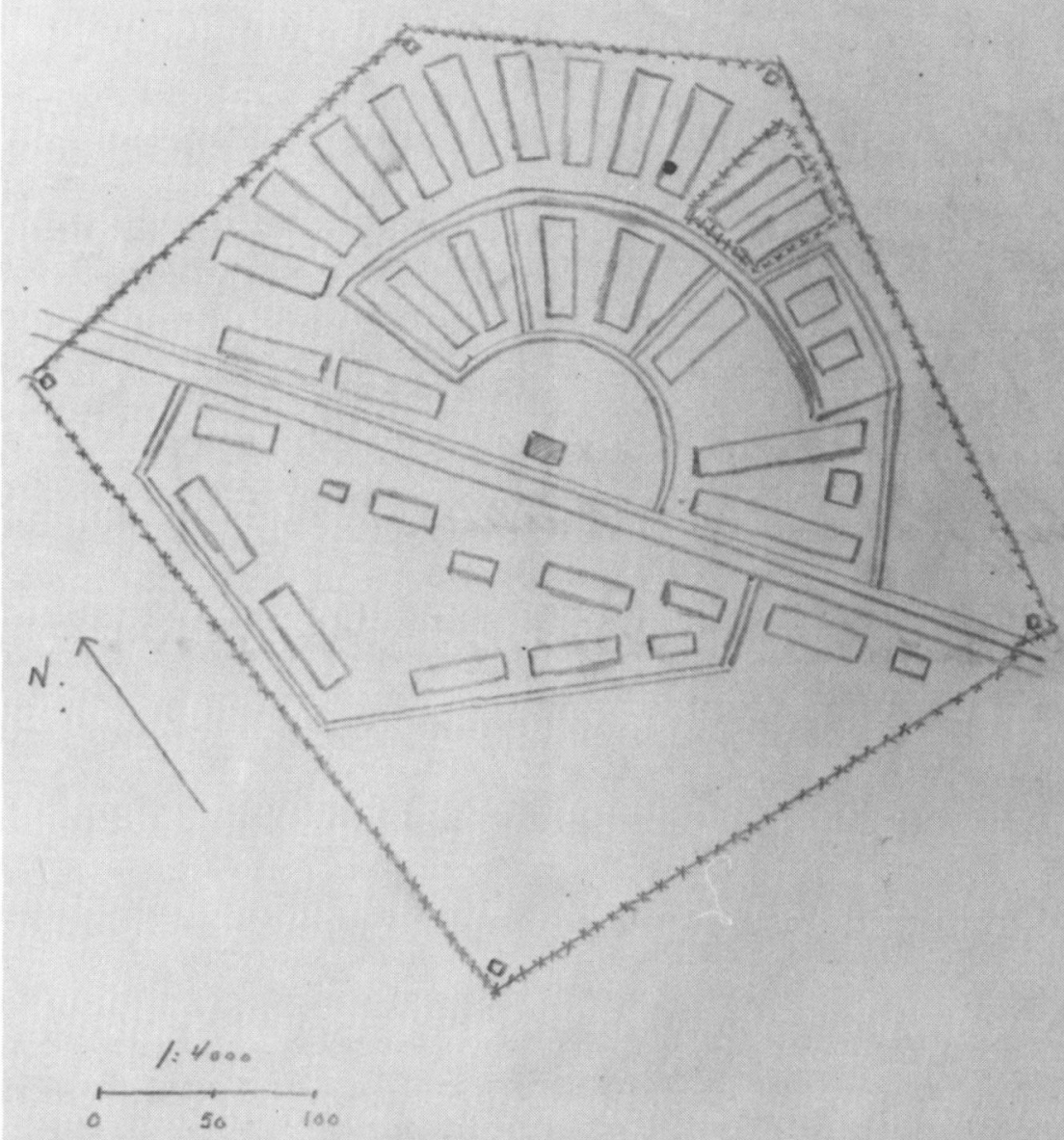

Tegning fra dagbogen $i$ Froslevlejren. De to indtegnede barakker i overste hojre hjorne var kvindebarakker. Forfatteren havde til huse i barakken til venstre herfor, angivet med en sort prik. 
enestående "organisationstalent«. Et udtalt ønske om det ene eller andet, straks forstod Jacob at fremskaffe det.

Vort arbejde i skoven er slut, desværre, nu skal jeg arbejde inde i lejren, det er ikke nær så rart.

Jeg har idag været »Häftling “ i to måneder. Ufatteligt, som tiden løber. Pakkespærringen er blevet ophævet, så kan jeg begynde at glæde mig til en pakke. Desværre er der kommet skrappere bestemmelser om pakkernes indhold, så jeg skal nok indstille mig på at ryge på en kold pibe. Men jeg håber meget på at få mine gummistøvler, for $\mathrm{i}$ dette våde efterår er lejrgaderne forvandlede til kanaler, og mine læderstøvler er utætte. Lejrens indbyggerantal vokser stadig, trods deportationerne.

Et par ord om selve lejren. Den er femkantet, og der er et tårn i hvert hjørne. Tårnet er bestandig besat med en vagtpost. Han har et godt dansk rekylgevær til sin rådighed. Endvidere er tårnet forsynet med en kraftig, drejelig projektør. Lejren er omgivet med to ca. to meter høje pigtrådshegn, der står med ca. en meters mellemrum. I denne gang mellem hegnene løber natten igennem nogle bidske hunde. Uden for det yderste pigtrådshegn er der så et minefelt. Ikke sjældent sker det, at en hare eller et rådyr løber mod en forbindelsessnor, og der lyder et brag. Det er altså ikke helt let at forsøge flugt den vej.

I lejrens østlige hjørne findes hovedindgangen, og herfra til det vestlige hjørne går en bred vej gennem lejren. Langs nordsiden af denne vej er der også et solidt pigtrådshegn, og inden for dette hegn er det vi bor $i$ Häftlingebarakkerne. Her er også spisesalen, værksteds- og sygebarakker og de to kvindebarakker, disse sidste er afskåret fra den øvrige lejr med pigtrådshegn. Syd for lejrens hovedgade holder germanerne så til. Her findes kontoret, besøgslokale, opholdsrum for vagtpersonellet og en villaagtig barak til Storbanditten.

Indgangen til fangelejren sker gennem hovedtåmet, der ligger midt på den øst-vest gående vej. Har vi været uden for lejren, sker det ofte, at man bliver visiteret. Neden for hovedtårnet ligger lejrens appelplads, og lejrgaderne stråler vifteformet ud herfra, så vagten $i$ hovedtårnet kan se ned gennem alle lejrgaderne og med rekylgeværet beskyde samtlige barakker.

I hver barak er der plads til 126 mand. Barakken vælger selv sin formand og næstformand. Disse to har den daglige ledelse af barakken. Barakformanden skal sørge for at vække om morgenen og sørge for at få fangerne stillet op til appel morgen og aften, når Meisteren kommer for at tælle op.

Vi har egen dansk lejrledelse. Øverst er lejrchefen, Lagerälteste. Det er kaptajn P. M. Digmann. Han er kontakten til tyskerne, og han holder dagligt møde med barakformændene, "sognerådsmøde“, og ved aftenappellen bliver 
lejrledelsens direktiver givet videre til alt folket. Lejren har sit eget "folkeregister" der omhyggeligt registrerer til-og afgang. Endvidere er der en depotforvalter, der står for udlevering af lagener, håndklæder og tæpper. Køkkentjenesten bestrides også af fanger. Vi har fremragende kokke fra gode restauranter i København. Så er der en "arbejdsminister“, det er en lidet attråværdig post. Han skal sørge for, at der stilles arbejdshold til brændehugning, halmfletning, de såkaldte "måtteludere «, til vej- og kloakarbejde m.m. Et særligt arbejdshold er »dørristekommandoen«. Egentlig tror jeg, de selv har etableret sig. De går rundt og fejer dørristene, men kommer let om ved det $\mathrm{og}$ bruger vist mere tid ved kortbordet, men de har en kost i nærheden som alibi, hvis der skulle komme inspektion. Endelig er der en spisegeneral. Hans opgave er at føre fangerne til spisning.

Tyskerne ser vi relativt lidt til. De er i tåmene, de går på inspektion $\mathrm{i}$ barakkerne, men der er altid i hver barak en dørvagt til at advisere, så de, der opholder sig illegalt $i$ en barak, kan fordufte.

12.11. Jeg har nu modtaget den længe ventede pakke fra Tom. De gode ting, hun havde betænkt mig med, var fjernet, men jeg nød at få varmt undertøj og mine gummistøvler, så nu slipper jeg for konstant at gå med våde fødder. Brev hjem har jeg måttet skrive. Men det er ret deprimerende at skrive legalt brev. Det må være på 20 linier, og når man ved det skal gennem forskellige censorer, er det ret begrænset, hvad man ønsker at udtrykke.

19.11. Lejren vokser stadig. Vi er nu 10 på vor stue, der var godt belagt med 8. De to sidste er en repræsentant Berthelsen og tandtekniker Leo Kærå, begge fra Århus. Kærå og hans kone skød Gestapo på, mens de lå i sengene. Konen døde. Kærå med flere projektiler $\mathrm{i}$ kroppen overlevede, men har gået uendelig meget igennem. Gestapos gerninger vil ikke blive glemt i hast.

23.11. Idag har vi været på skansearbejde i Sydslesvig. 500 mand blev vi udkommanderet og under stærk bevogtning i busser kørt over grænsen ved Sofiedal og videre mod vest omtrent til Ladelund. Der blev vi sat til at grave pansergrave. En grøft på godt en meters dybde og ca. tre meter bred. Det forekommer fuldstændig tåbeligt. Når de allierede har kunnet komme over kanalen til Frankrig, så vil det arbejde, vi her laver, næppe kunne standse deres fremrykning. Vi lavede nu ikke ret meget gravearbejde, og skafterne på mere end hundrede spader og skovle brækkede, hvad vi hjalp til med. Nogle af vagterne blev rasende og brølte op om sabotage, andre var komplet ligeglade. De tyske værnemagtssoldater, der skulle passe på os, var alle klare over, at krigen var tabt, og de fandt arbejdet lige så tåbeligt som vi. 


\author{
H $u$ s o r d e $n$ \\ for \\ Silkerhedepolitiets politifangelejr \\ i. Horser $\phi d$.
}

1) Hvor Fange sikw ubetinget rette sig efter donne tusorden og eftor" Opsyns- $\mathrm{g}^{-1}$ Bevogthingsmandskabets saevel som Barakformandenes Anvisninger。

2) Fangerne naa 1klre anvonde den tyske Hilsen. Fangerne skal til enhver Tid Iorholde $\mathrm{sig}$ anstazndigt of korrekt overfor Opsynsog Bevogtningsmardskabet og altid udvise god Foldning.

3) Hver Pange or forplittet til,

a) at holde sin stue ren og i. Orden,

b) ved Mrigivelse at overgive sin stue i ronholdt Stand,

c) at skeane Inventaret,

d) otraks at nolde aile saorligo Begivenheder og milatedevicerelsez as Uthj。

4) Fingexne 1 en Barak" danner Barakstyrken. I Spidsën forr hver Berckstyrke staar en Barakio raand, der bliver uanaevmt ira. Periode til Eëriode。 Barakiomonaen er ansvarlig for

a) 20 , orden og Renlighed $i$ sin $3 a r e k$,

b) den Iuldstaundig og ordentifge Beholdning af Stue- og

Barakinventcret

4) Gannomf

d) Fuldtaliligheden af Fangerne i sin Barnk.

Ien skal desuden straks melde

e) sile suerligu Hrendelser,

f) aile Overtxaodelser af Husordenen ti. den vagthavende Fecn selbutjent eller imbedsmand.

Vod Unaladelse ef at melde udsuetter han sig for at bifve

behandlet som on han selv havde overtraadt Eusordenen.

5) Por politflangelejron gcolder følgỉnde Tjenesteplan:

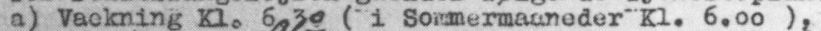

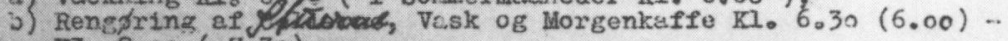
ka. $8.00(7.30)$,

c) Formidingetjenusto 1følge seerlig Bestommelse KI. 8.00 (7.30)I. 12,00 ,

d) Kidang KI. $12.30-13.30$,

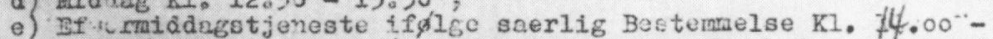
til Mjrkets Wremou:d ( 1 nfzukkede Rum - Vaerkstoder - min 1 st til Ki. 17.30 )

f) Aftensmad KI. 18.00 - K1. 19.00,

g) Luset slukkes Kl. 21.00。

6) Dot ex pangerne forbudt:

a) at stec pea Borde, Senge- of Sengesteder,

b) at snavse Vaegge I genstande og andre ling til eller at pdelaecge disse,

Husordens reglement i Freslev. Man anvendte det, der gjaldt $i$ Horsered. I punkt 2 hedder det, at det er fangerne forbudt at anvende den tyske hilsen. Det var der nu absolut ingen af fangerne, der ville dromme om at gore. 
Tre dage varede dette skansearbejde, så blev det indstillet. Muligvis fandt man, det var nyttesløst. Fra lejrledelsens side var der blevet kraftigt protesteret imod, at vi blev anvendt til dette arbejde; som politiske fanger skulle vi være fritaget herfor, men i krigstider giver den stærke pokker i Haag og andre konventioner.

26.11. Blandt fangerne er der efterhånden en del præster, og de indbyder til gudstjeneste om søndagen i de forskellige barakker. I en af de største stuer samles »kirkegængerne«. Man sidde på køjerne og på gulvet. I det ydre er der jo ikke meget, der minder om en kirkesal, men det er underordnet, men når der som idag sad fire mand ved et bord og spillede kort under prædikenen, virker det ejendommeligt. Lidt mere taktfølelse kunne de godt have vist, men de hørte til på den stue, og havde selvfølgelig lige så god ret til at være der, som vi andre.

29.11. Nu var vi lullet ind i en illusion om, at det var slut med deportationer, fordi vi var kommet ud af den regelrette bane med transport, hver gang datoen endte på 5. Men så kom der én idag. Det slog hårdt. Sug i mellemgulvet, mens oplæsningen står på. Kommer du med denne gang? Navnene bliver læst op i alfabetisk rækkefølge. Andersen, Erik, Andersen, Knud. Andersen, Svend, så er man kommet forbi $P$, og har klaret frisag. Men tyskerne har tre lister, så tre gange skal vi gennem spændingen. Det er modbydeligt.

$\mathrm{Vi}$ ved nu mere om KZlejre end for nogle måneder siden. Vi har hørt beretninger fra de enkelte, der er kommet tilbage efter et par måneders ophold, vi har hørt om mange, der er døde dernede. Det er ikke "Greuelmärchen « som tyskerne siger. Det er barsk, brutal virkelighed. Lidt overdrevent havde vi vel troet, at beretningerne var, men selv det mest barbariske, man hører, kan ikke beskrive virkeligheden. Ubegribeligt at mennesker kan overleve. Det vil tage generationer inden den tyske nation får afvasket denne skamplet.

Et lettelsens suk undslipper, når oplæsningen er til ende, så trak man frinummer endnu engang, og alligevel er man ikke lettet. Gode venner og kammerater sendes en uvis skæbne imøde, for mange betyder det en dødsdom. Og udvælgelsen til disse deportationer synes ikke at have nogen klar linie. Hvis folk er taget i samme sag, kan det ske, at fem deporteres, fire bliver her og en løsladt. Idag blev således en fredelig arbejder med sukkersyge, der var taget af Gestapo på en tilfældig gaderazzia, sendt sydpå. Vi er oprørte over dette retsløse, barbariske system, der ovenikøbet er et klart løftebrud fra tysk side. Frøslevlejren blev oprettet med den aftale, at danske 


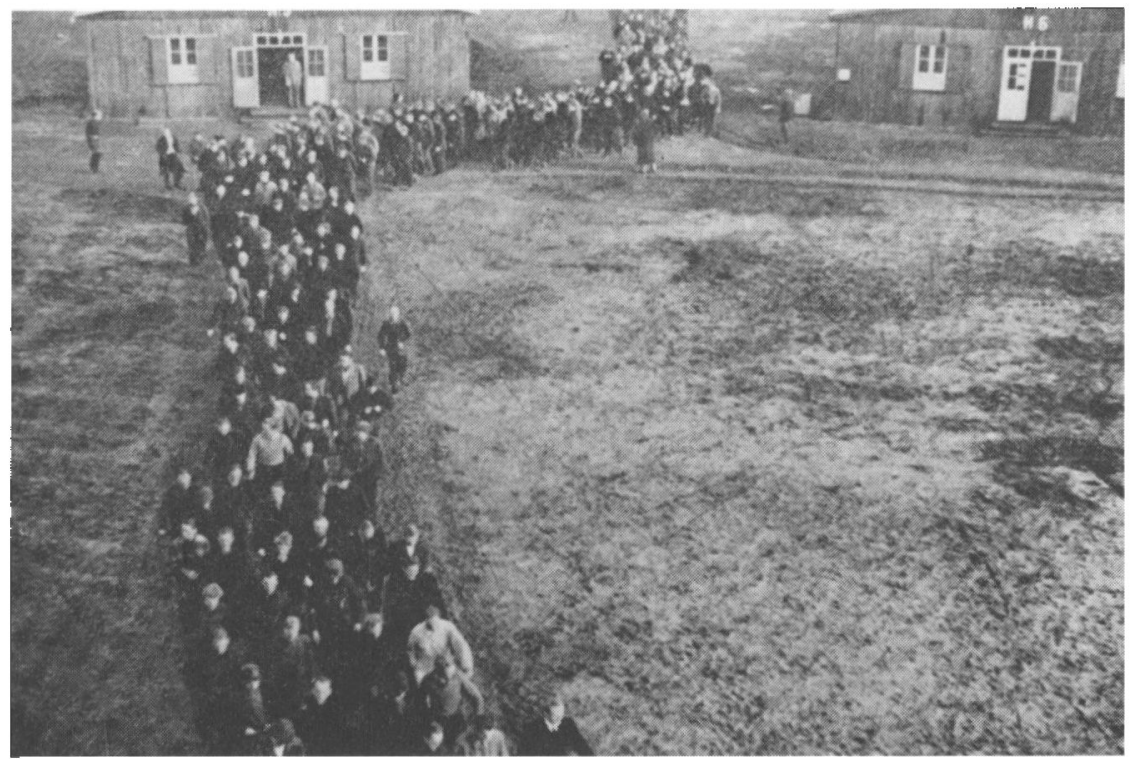

Fangerne fores til spisning. Det skulle forega $i$ rakke og geled. Barak H.6 til hojre i billedet var sygebarak. (Foto fra: Fanger i Froslevlejren 1944-45 v. J. Maagaard).

fanger ikke skulle sendes til Tyskland. Alle fanger her - stort set - erkender besættelsesmagtens ret til at arrestere og internere os, det er "spillets" regler, hvis man er gået ind i modstandsarbejdet, men Gestapos tortur og deportationerne er en brutalitet, der hører hjemme i en mørk middelalder.

De, der er udtaget, skal nu pakke og hjælpes, og de bliver det, enhver giver, hvad han har af varmt tøj og tætte støvler. Ens sidste cigaretter får de også med. Det ved vi er god valuta i lejrene og kan efter rygterne hjælpe over mange prøvelser.

Midt under det hele blev jeg kaldt til Digmann, der bad mig overtage stillingen som depotforvalter. Det havde desværre den ulempe, at jeg skulle flytte fra barak H.15 til H.5., men tillige den fordel, at jeg i H.5. kom på en tomandsstue, som jeg delte med en lærer Viggo Nielsen fra Horsens. Han er en behagelig kontubernal.

Vi to har travlt med at inddrage lagener og tæpper, optælling m.m.

2.12. 1. søndag i advent. Vi sang: Vær velkommen Herrens år til gudstjenesten i barakken. Midt under prædiken blev vi afbrudt. Germanerne kom på inspektion. Det er forbudt at holde gudstjeneste. Tyskerne har kun en gud, der hedder Adolf. Så gik Carl, Ole og jeg en lang tur i øsende regn. 


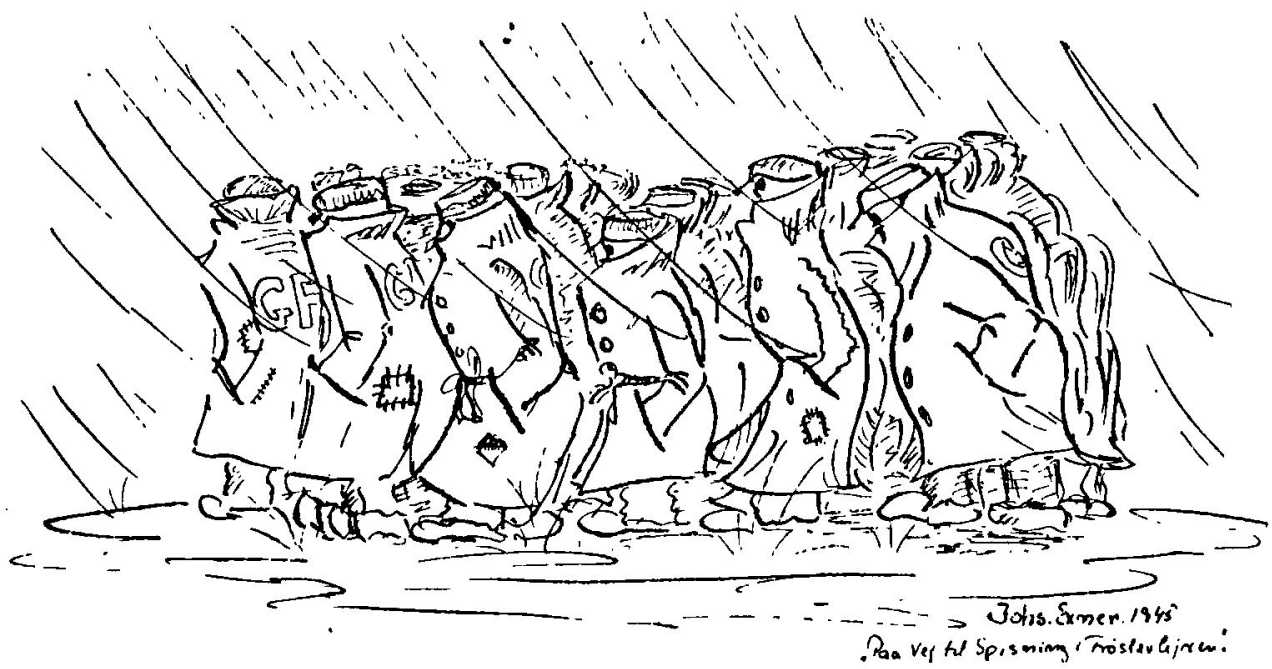

Som tegneren Johs. Exner opfattede den samme situation.

5.12. Så er der gået tre måneder siden jeg blev arresteret. Jeg har svært ved at indstille mig på, at det skal vare længe endnu, men det bør jeg nok gøre. Selv om jeg har mere travlt med depotarbejdet, end hvis jeg havde været på f.eks. et jordhold, så snyder jeg mig til hver dag at gå 20 omgange på "strandpromenaden ${ }^{6}$, for dog at holde mig lidt $\mathrm{i}$ form.

Jeg havde egentlig troet, at der var mere ro på en tomandsstue. Men vor stue bliver brugt til sangøvelser og studiekredse. jeg savner meget noget ordentlig lekture. Længes hjem. Har et alvorligt angreb af "fængselsfis«. Rygter svirrer, rygter afkræftes, de fleste af dem er ønsketænkning. Juleaften på Nørmark har jeg afskrevet.

10.12. Vi har meget travt på depotet. Der skal komme en transport fra Tyskland på ca. 200 mand syge. Vi må finde plads til dem i barakkerne og have lagener og tæpper parat.

Pastor Magle holdt gudstjeneste her på depotet idag. Han gik ud fra Matthæus 5. kapitel: Men jeg siger eder jer: Elsk jeres fjender, velsign dem, som forbander jer, gør godt imod dem, der hader jer, og bed for dem, der forfølger jer.

Han gjorde det smukt. Men det er svært at leve op til.

Hver søndag, efter jeg er flyttet fra min gamle stue, går jeg ned til kammeraterne der og drikker eftermiddagskaffe med dem. Så ryger jeg den til søndagen gemte cigar og går lang tur med Carl. 
11.12. Kl. 1 nat blev jeg kaldt op. Nu kom transporten fra de tyske lejre. Vi, der arbejder på depotet, var oppe nogle timer for at være behjælpelige med at få de ca. 200 indkvarteret, og jeg fik således et første hånds indtryk af den behandling, de havde været ude for. Det var politifolk, der alle var blevet taget d. 19. september, og deres forbrydelse var, at den højere Pancke ikke kunne lide dansk politi. Det havde kostet dem $3 \mathrm{mdr}$. i KZlejr. I de få måneder var mange af dem blevet til skind og ben, og vi måtte bære dem ind, $o g$ for en del vil det vel nok være tvivlsomt, om de overlever, og mange vil være mærket for resten af livet, og så har de endda haft det relativt godt. Vore illegale kammerater er ude for en meget værre behandling. Netop idag bringer Nordschleswische Zeitung, den eneste avis, vi må få her i lejren, en ledende artikel »Ritterlichkeit im Kriege", skrevet af pastor Schmidt, Vodder. Han skulle skamme sig, og det samme skal de danske forretningsfolk, der i samme nummer averterer på tysk. Det forekommer unødvendigt.

13.12. Har fået flere beretninger fra samtaler med de hjemvendte politifolk. Det er gruopvækkende. I lejrene regnes menneskeliv for intet. Ellers gode rygter idag. Vestfronten skal være i skred. Optimisme taler om, at vi kan komme hjem til jul. Jeg gør mig dog ingen illusioner. Er sløj og øm af den sprøjte tyfusvaccine, jeg har fået. Tobakken sluppet op. Humøret skidt.

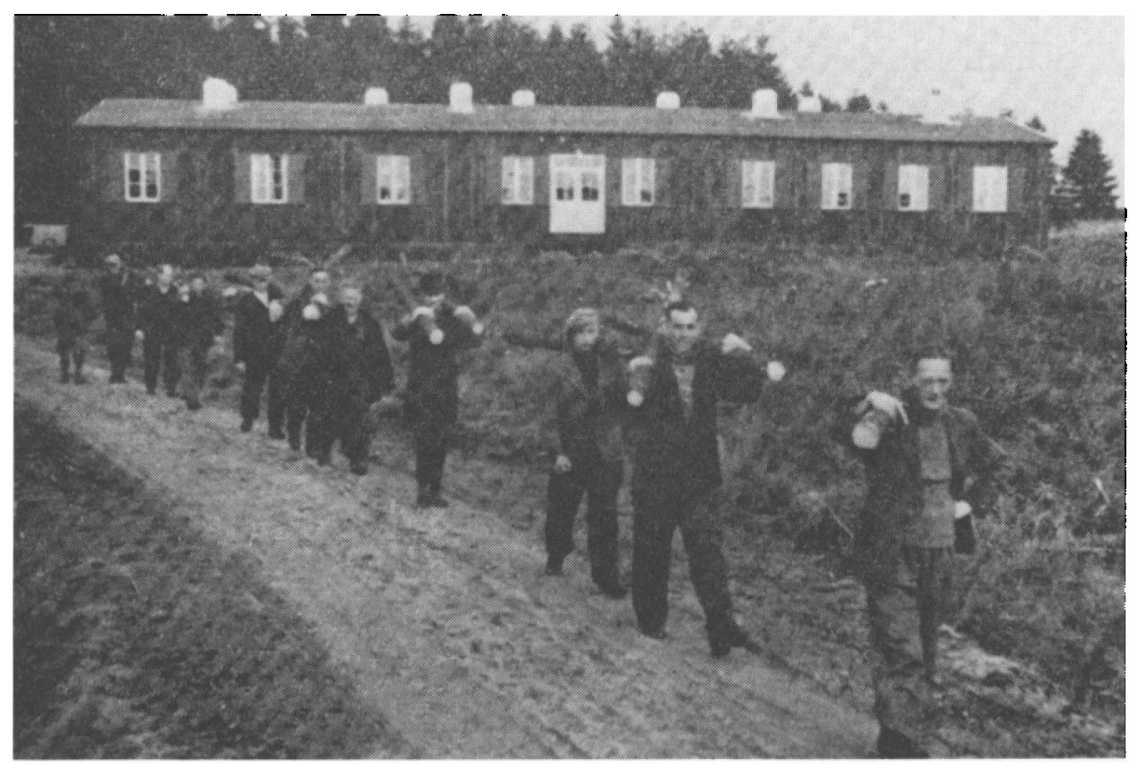

"Pigtrådskommandoen « rykker på arbejde. Fangerne skulle indhegne sig selv. Forfatteren gd̊r som nr. 2 i rakken. (Foto fra J. Maagaards fernavnte bog). 
15.12. Viggo og jeg flyttede idag fra depotet ned i vor gamle barak, hvor vi nu residerer i stue 2. Var på vej over i Einzelhaft med en spand kul, da jeg pludselig gennem pigtråden kunne se Tom i lejrgaden. Hun havde uventet fået en besøgstilladelse, og det var et dejligt besøg, selv om det skal overvåges af en dansk SS. Hun havde billeder med af børnene, og selv så hun glad ud, men det er nok for min skyld. De 20 minutter går desværre meget hurtigt. Efter sådan et besøg savner jeg mine tre endnu mere. Trods dette en dejlig dag. Toms besøg, billederne af ungerne, flytningen tilbage til H.15. Man må søge de små glæder og det positive i denne tilværelse.

17.12. 8 mand kom i nat hertil fra Tyskland. Havde betjentene været medtagne, så var disse 8 de rene skeletter. De var lette at bære, vejede omkring $50 \mathrm{~kg}$. Et par af dem var vi ikke sikre på levede. Det gjorde de, men hvorlænge. Vi har en dygtig stab af læger i lejren, men de mangler de hjælpemidler, et hospital har til rådighed. Mange skal være døde dernede, men noget konkret om navne er det svært at fả vished om. Vejret atter mildt. Tankerne går bestandig hjem, hvor vil jeg dog gerne hjem til jul.

Der går rygter om transport mod syd. Kunne de dog ikke fritage os for det til efter nytår. Jeg har for alle tilfældes skyld skrevet et illegalt brev, der skal afsendes, hvis jeg skal til Tyskland.

20.12. Jeg kan stadig mærke tyfusindsprøjtningen og har tillige fået noget pandehulevrøvl, så jeg blev i sengen om formiddagen og læste Raskolnikov af Dostojewski.

Gustav Grüner, ${ }^{7}$ min gamle ven fra rekruttiden, kom idag hertil med en transport fra Vestre. Hyggeligt at træffe ham efter de mange år. Vi er efterhånden en hel pæn repræsentation af gamle gardere. Viggo lægger i aften kabale. Går den op tre gange, kommer han hjem til jul.

21.12. Årets korteste og mørkeste dag, og det på mere end en måde. Der gik nemlig idag atter en transport til Tyskland. 114 af vore venner og kammerater skulle af sted. Vor barakformand, Edelmann og min kontubernal Viggo, der iaftes troede han skulle hjem til jul, var blandt dem der skulle af sted. Det kneb for Viggo. Der hersker en dyster stemning i lejren. Smilet er borte. Vi var ellers begyndt at forsøge at få lidt julestemning frem.

22.12. Idag var der igen stor travlhed på depotet, men anledningen betydelig mere opmuntrende end igår. Der er kommet juleamnesti, og ikke mindre end 85 blev løsladt. Jeg har travlt med at lave små julegaver. Lidt skal det mærkes, at det er jul. Fik en udearbejdende til at fremskaffe et lillebitte 
juletræ. Det er pyntet med »lametta« fremstillet af de strimler sølvpapir, de engelske flyvere kaster ud for at forvirre luftforsvaret. Hess, den tyske Meister, kiggede noget skævt til det ved afteninspektionen, men lod det dog passere.

23.12. Atter idag en del losladelser. Jeg var ikke blandt de heldige. Carl flyttede idag herind på stue 2 , og vi nyder begge at være flyttet sammen. Tankerne er hele tiden hjemme, hvor de nu har travlt med de sidste juleforberedelser. Der bages og brases. Pyntes op både inde og ude. Lå længe og sludrede med Carl, efter vi var kommet i seng. På en stor stue med mange er han ikke af mange ord. Her folder han sig ud. Det var dejligt, om han og jeg kunne holde sammen her til afslutningen på dette kapitel.

24.12. Juleaften. K1. 16 var der julegudstjeneste. Dejligt at synge de kære, kendte julesalmer. I spisesalen var der rejst et stort juletræ. Et kor sang: Julen har englelyd. - Digmann holdt juletale, og vi fik en fin middag. Flæskesteg og æblegrød. Fra Røde Kors var der en julepakke til alle med tobak, æbler og slik. Der bliver gjort meget for at gøre julen let for os. Tankerne går til vennerne $\mathrm{i}$ de tyske lejre, men mest går de hjem. Hvordan bliver deres juleaften? Efter aftenoptælling var der forskellig underholdning på gangen, og der var skrevet en sang på melodien Højt fra træets grønne top. Den handlede om brug af dynamit, maskinpistoler og illegalt trykkeri. Senere drak Carl og jeg aftenthe på stue 3. Det blev trods alt en hyggelig juleaften.

26.12. Vi skal ikke arbejde $i$ juledagene, så der er tid til lange spadsereture. Den danske forvaltning overgår sig selv. Glimrende middag og overdådigt aftensbord. Vi bliver meget forkælede. De derhjemme skulle blot vide, hvor godt vi har det. Var til løjtnantsthe om eftermiddagen. Vi er 9 løjtnanter fra livgarden, så regimentet er smukt repræsenteret. En havde tegnet et smukt "festtelegram", som vi underskrev. Det blev sendt illegalt til kong Christian som nytårshilsen.

29.12. Stor og glædelig overraskelse idag. Sonderbesuch af Tom midt om formiddagen. Vi fik en halv time sammen, og det er dejligt at se hende og høre om børnene og nyt fra hjemmet. Mange gode venner rækker hende en hjælpende hånd, men hun har også meget at stå $\mathrm{i}$, mange problemer med Nørmark. Og her sidder jeg ude af stand til at hjælpe. Det er bittert. Gid den krig dog snart må være forbi, så det kan blive plovtid påny. 
31.12. Den sidste dag i 1944. Lang tur med Carl. Om aftenen var der arrangeret forskellig underholdning på gangen $\mathrm{i}$ anledning af årsskiftet. Ole talte godt, ikke svulstigt og rørstrømsk, men netop det, der skulle siges i den situation, vi befinder os $i$.

1.1.45. Høj himmel og tindrende frost. Røgen stiger lige op fra de mange kakkelovne $\mathrm{i}$ barakkerne, og den grimme dunst af brunkul, der i tåget og vådt vejr ligger over lejren er borte. Nu ligger et nyt år foran os. Hvad gemmer det $\mathrm{i}$ sit skød? Det altoverskyggende ønske er krigens afslutning, og at vi atter kan få et frit Danmark.

3.1. Atter regn og tø. Jeg er glad for mit arbejde på depotet. Tiden går godt, inden man ved af det, er dagen omme. Om natten larm i luften. Vore venner er på vej.

5.1. Vaccineret for fjerde gang mod tyfus. Det er en fremragende foranstaltning vore læger har fået arrangeret, at vi alle bliver sprøjtet mod alskens ondskab, så vi har noget at stå imod med, hvis turen skulle gå mod syd. Johnstad Møller ${ }^{8}$ holdt foredrag om aftenen om treårskrigen. Det gjorde han godt. Aftenthe sammen med Carl. Vi rister et par skiver organiseret franskbrød på kakkelovnen og har det hyggeligt. Idag fire måneder $\mathrm{i}$ fangenskab.

10.1. Federspiel, der er lejrens spisegeneral, blev idag sendt til København. Hvad det indebærer, ved man aldrig, men det er sjældent for det gode. Digmann udnævnte mig til hans efterfølger.

11.1. Der er adskillige materielle fordele ved at være spisegeneral. I stedet for havregrød spiser jeg nu havregryn. Jeg har også takket være min bevægelsesfrihed $\mathrm{i}$ køkkenet større mulighed for at organisere lidt rart til stuerne i barakken. Idag fik jeg nogle af SSernes lækre koteletter. Jeg gav deres modbydelige vagthunde skylden for tyveriet.

12.1. Atter en af lejrens sorte dage. Op kl. 4. 232 mand blev udtaget til transport til tyske lejre. Gode folk i massevis. Holger Petersen ${ }^{9}$ og Erik Svendsen $^{10}$ skulle med denne gaing. Det er forfærdelig deprimerende at opleve.

19.1. Man lærer mange forskellige at kende, som det både er sjovt og udbytterigt at snakke med. Nordschleswigsche Zeitung bringer nu oplysning 
om en stor russisk offensiv. Mon det skal blive afslutningen. De tyske planmæssige tilbagetrækninger fryder os.

Udlevering af tobak idag. Det kom på et tørt sted. Der var stor mangel i lejren, selv om der spares. Af 10 cigaretter kan der blive 13 cigaretter, idet "skoddene" gemmes, og af hver tre kan der rulles en ny cigaret. Der er kommet tilladelse til at tegne abonnement på "Fædrelandet «. Det bliver nu næppe noget stort antal, der vil benytte sig heraf.

Carl og jeg slutter gerne aftenen med et parti skak.

20.1. Lang tur med Gustav. Vi talte blandt andet om lejrens sammensætning. Den er vel stort set et udsnit af Danmarks befolkning med alle erhverv repræsenteret. Mit eget erhverv er vel nok svagest med i forhold til sin størrelse. Partierne er stærkest repræsenteret med kommunisterne. De holder tæt sammen, synes, at de holder sig noget for sig selv. Deres forudsætning for at gå ind i modstandskampen er også forskellig fra vor.

23.1. Vaccineret anden gang for meningitis. Ivrig debat om kommunisme på stuen, som her i barakken har navnet »Røde oktober“, som følge af sin belægning af kommunister. Debatten var varm. De er stærke i troen på deres ideologis ufejlbarlighed. Jeg blev nu ikke omvendt og bliver det aldrig.

Rygter er her en masse af. Russerne går godt frem. Ufatteligt at tyskerne ikke kan - eller snarere rettere vil - se, at spillet er ude. N.Z. er interessant læsning i denne tid. Papir er »tolle«.

26.1. Idag et flugtforsøg. En mand forsøgte at komme igennem minefeltet. Det kostede ham livet. Jeg kendte ham ikke. Mærkeligt at høre rekylgeværet bjæffe fra tårnet og vide, at det er en af vore kammerater, de skyder efter.

27.1. Den dræbte fra flugtforsøget igår blev idag ført ud af lejren. Det var pauvert at se på. En umalet kasse på en lastbil, en lille blomsterbuket og en dame fra Røde Kors som eneste følge.

31.1. Pakke hjemmefra. Tobaksrationen er efter tyskernes påbud beskeden, men der var et par gummistøvler med, så nu har jeg erstatning for det par Viggo fik, da han måtte af sted til Tyskland.

Har gået lange ture med Niels," Jørgen ${ }^{12}$ og Gustav. Gode samtaler om meningen med livet, religion og fremtiden. Gustav kunne følgende lille digt af Piet Hein.

"Et venligsindet orkester

tog stade ved Rådhusets fod. 
Der samled sig nogle gæster, der stod og tænkte på noed, for musikken har jo en dragende, en rent ud besættende magt, og så er der noget betagende, ved dette opbud af - takt.، Det er et prægtig ordspil.

1.2. Så blev det februar. Mon krigen slutter i denne måned? Hvor man dog ønsker, det må ske. Nu er der da ødelagt nok, og hele verden er led og ked af krig. Udfaldet kan jo ikke længere diskuteres. Det er et voldsomt greb, Nazismen har om den tyske befolkning. Gode frontberetninger.

3.2. Johnstad holdt $i$ aftes foredrag om Mysundedagen. En smule svulstigt. Når vi går på "Sandpromenaden« har vi udsigt til dejlige farver. Vissent, stærkt gult græs, rødsort lyng og i baggrunden de blågrønne graner, mod hvilke tre hvide birkestammer tegner sig skarpt. Har læst Karen Blixens "Den afrikanske farm«. Hvem der dog kunne skrive et sådant dansk. Det er lørdag, og jeg har skrækkelig hjemve.

4.2. Om eftermiddagen en skarp diskussion på stue 3. Emnet var Sydslesvig efter krigen. Nogle ville have grænsen sat ved Ejderen, andre ved Dannevirke. Nogen enighed blev ikke opnået, det skulle da være, at spørgsmålet skulle tages op. Bølgerne vil nok efter krigen gå højt som efter første verdenskrig mellem Åbenrå- og Flensborgfolk. Det var rart at konstatere, at enkelte røster om tvangsforflytning blev nedstemt. Som spisegeneral bespiser jeg nu 2000 mand tre gange daglig.

6.2. Idag et med længsel ventet besøg af Tom. Børnene var med. Ole kunne ikke rigtig kende sin far og var med skam at melde mere interesseret $i$ tolkens uniform. Jeg havde skrevet et brev til Tom og pakket det sammen til en lille kugle. Det fik jeg lagt ned $i$ hendes lomme. Pludselig ser jeg Ole få fingre i det. Hurtigt måtte jeg have ham på skødet og taget det fra ham, og så atter lagt i lommen hos Tom. Heldigvis gik det godt, uden at tolken blev nysgerrig.

Det er vidunderligt at få besøg, men modbydeligt at skulle sige farvel, og humøret er ikke på toppen, når jeg ser de tre vandre ud af lejren. Til alt held fik jeg besøg af Bomhof, og han var endnu mere nedtrykt, så det hjalp at skulle opmuntre ham.

7.2. Idag kom der 200 nye pensionærer fra Vestre fængsel og andre steder, så mine bordplaner blev kuldkastet; men jeg fik da skaffet mad til alle. Bare det ikke medfører, at der atter skal gå en transport til tyske lejre. 
10.2. 25-årsdagen for afstemningen. Underligt på denne dag ikke at se et Dannebrog. Landsdelen plejer at have flag fra hvert hus og hver gård. Måske er der flagforbud ude, og måske er det forbudt at fejre dagen. Vi gjorde det her i barakken, og det sker også i andre barakker, hvor der er sønderjyder. Vi er nogle stykker, der har haft travlt med at mangfoldiggøre sange. Den blå sangbog findes ikke her. Vi har skrevet "Du skønne land-« og «Det haver så nyligen regnet $-\leadsto$ i mange eksemplarer. For størsteparten af beboerne her er det nyt at fejre denne dag. Det kender de ikke. Mange af dem er født efter 1920, så for dem er det ikke noget minde. Carl fortalte til indledning om baggrunden for d. 10. februar. En sønderjyde fortalte træk fra fremmedherredømmet og afstemningen. Oberst Christensen, der havde været med, da de danske soldater rykkede ind i Nordslesvig d. 5. maj 1920, fortalte om oplevelser fra den dag. Det blev en god aften, og den mest særprægede afstemningsfest, jeg har deltaget $i$.

14.2. Idag kom der en af de deporterede betjente tilbage fra en tysk KZlejr. Dog kun for at dø nogle timer senere. Der er meget brum i luften om natten. Den tyske avis er meget forarget over englændernes angreb. Den forargelse kom ikke til orde, da Englands byer skulle udraderes. Atter idag det mest

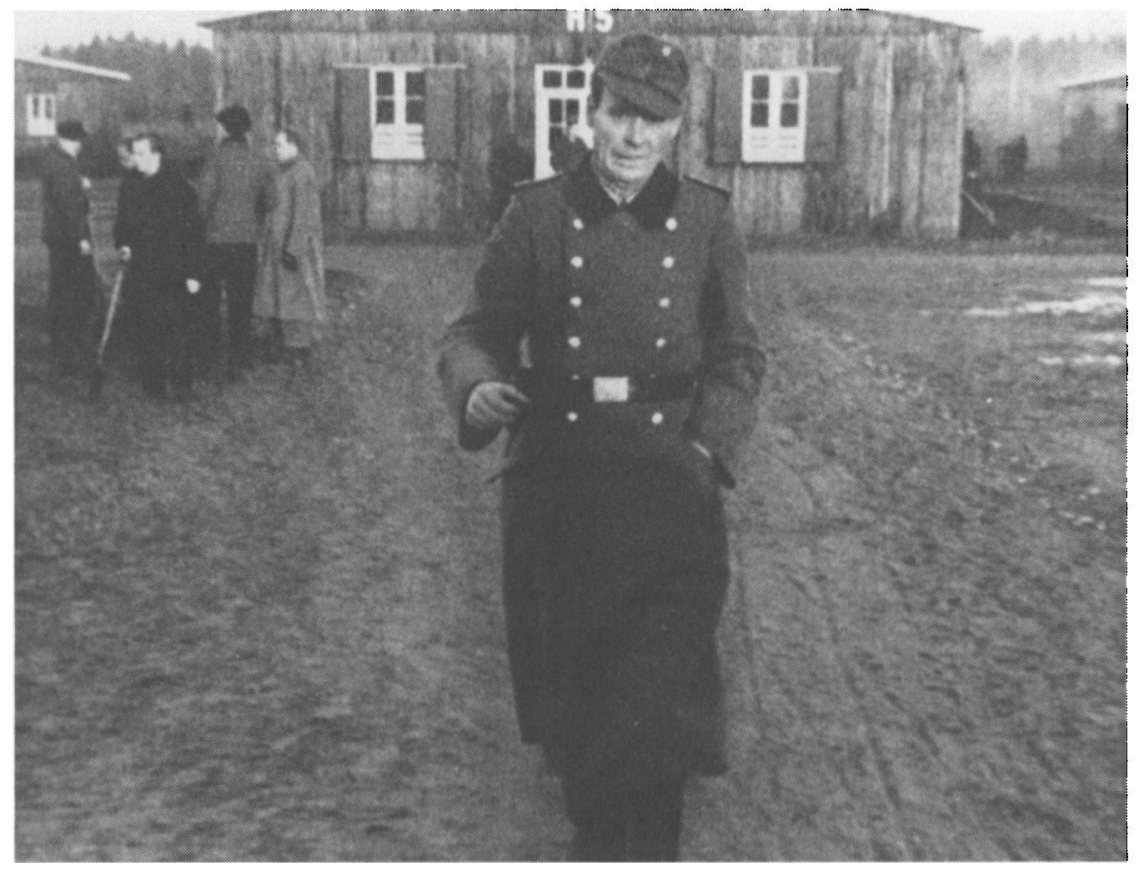

Den tyske lejrchef Wassermann. (Foto fra J. Maagaards fornavnte bog). 
strålende forårsvejr. Nu dukker de første vintergækker op i haven, og på lune pletter i markhegnene, hvor der er sydsol, glimter det gult af følfod. Nu bliver der travlhed i marken, og jeg sidder her uvirksom og kan intet gøre.

16.2. Atter en af de sorte dage. 233 mand blev sendt til Tyskland. Bomhof jun. blev i hast lagt på operationsbordet, hvor lægerne fjernede hans blindtarm. Så fik han $\mathrm{i}$ al fald frist til næste deportation. Jeg fik et 10 minutters besøg af Tom. Så kunne hun konstatere, at jeg atter havde klaret frisag. Det var et meget forceret besøg. Men dejligt atter at ses. Bag efter gik jeg tur alene og plejede min nedtrykthed.

20.2. Jeg har fået en vaskeveninde i pigebarakken. Det er Gøga, ${ }^{13}$ en halvkusine. Det er at se på vasketøjet, at det har været gennem pigehænder. Når jeg selv gør det, er resultatet knap så godt. Gøga tager sin indespærring i stiv arm. Nu bliver vi alle TB undersøgt.

21.2. Forårsvejr, så jeg er helt syg efter at komme ud. Jeg ved, der er uendelig meget at gøre på Nørmark. Dette ophold kan måske blive skæbnesvangert, det vil i al fald givet sætte starten økonomisk meget tilbage. I sådan et vejr er det vist sværere for en bonde end for byfolk at være spærret inde. Læser Adam Homo. Det har jeg megen glæde af, og jeg lærer nogle af de bedste vers udenad.

23.2. Talte idag med en, der havde været med de såkaldte "Himmelfartskommandoer « i oktober, da tyskerne fandt på at sætte fanger her fra lejren i en aflåset godsvogn foran lokomotivet for at afholde sabotører fra at sprænge togene $i$ luften. Det havde været 8 ret anstrengende dage $i$ en kreaturvogn med halm på gulvet som sengeleje. Han fortalte mange sjove træk fra turen. De var kommet på talefod med deres vogtere, som de bestak med cigaretter, så de fik lejlighed til at købe aviser og mad og tobak og også snakke lidt med folk på stationerne. Han havde taget det som en afveksling i fangenskabet.

Jeg lærte dette digt idag. Det skal vist være skrevet af en norsk fange. ${ }^{14}$

Før deltes folket vandret

i dets forskellige lag,

men voldsmænds svig og uret

har lært os, at idag

kan folket deles lodret,

i de, som ikke dur,

og de, der holder ryggen rank

selv mod en mur. 
24.2. Det er utrolig mildt. $5+$ grader, og vi er endnu i den normalt hårdeste vintermåned. Det er gråvejr, men alligevel en dejlig belysning. Lyngbakkerne uden for pigtråden er rødbrune, og som en fin kontrast står de blågrønne graner. Jeg har tre birketræer med hvide stammer, som jeg glæder mig over på mine vandreture. Bladene var grønne på dem, da jeg ankom her til lejren, så blev de gule og faldt af, og nu står de med nøgne grene. Mon jeg skal opleve løvspring på de birke, inden jeg kommer herfra?

25.2. Søndag. Kirkegang om formiddagen. Om eftermiddagen var der revy på barakgangen. Der er mange, der både kan synge og spille. Lang spadseretur i regn og blæst.

26.2. Vejret er som en dag $i$ april. De må være $i$ fuldt sving med markarbejdet på Nørmark. I disse dage er det 10 år siden, jeg kom til Søgård, og et år siden, jeg solgte den. Det havde været bedre, om Tom havde siddet der nu i stedet for på den store gård.

Kærligt brev fra Tom idag. Selv om det kun er på de 20 tilladte, censurerede linier, så er det dog et vidunderligt livstegn at modtage. Men længslen efter hjemmet bliver ikke mindre efter at have fảet brev. Et rygte vil vide, at Moustgaard er død i Tyskland. Han var en god kammerat på stue 11 , hvor jeg boede $\mathrm{i}$ den første tid. Jeg satte stor pris på ham. Alt for mange af de gode går til i denne ulvetid.

28.2. Lærkerne jubler, og det kribler $\mathrm{i}$ mig for at komme til at tage fat $\mathrm{i}$ stedet for at gå ørkesløs her. Underligt slet ikke at være med $\mathrm{i}$ tra vlheden på gården, hvor der er så meget at gøre, og sært, hvis jeg ikke skal se de første grønne spirer komme op af jorden.

2.3. Storbanditten har dekreteret forbud mod gudstjenester i lejren. Det er småligt, men bliver bestemmelsen overtrådt, truer han med deportation af præsterne, så vi bøjer os.

3.3. Carl og jeg løber tur, og så en kold bruse. Dog forhindrer mit arbejde som spisegeneral, at jeg kan gøre det, når jeg står op. Der er en del bøvl med at være general. Tyskerne finder snart på ét, så på noget andet. Så skal der marcheres $\mathrm{i}$ geledder med tre mand og så med fire mand, og også tidspunkterne, der skal mødes på, ændrer de uden nogen praktisk motivering. 
5.3. Idag har jeg et halvt års jubilæum som hæftling. I seks lange måneder har jeg været skilt fra Tom og ungerne. Kan denne forbandede krig dog ikke snart få ende. Udfaldet af den er jo givet.

6.3. Carl blev 50 år idag. Han og jeg drak morgenthe sammen på vor stue. Jeg havde "organiseret" nogle SS rundstykker. Vi havde det hyggeligt. Om aftenen havde vi gæster og hyldede ham. Fra køkkenet havde jeg skaffet en lille varm ret og mange slags pålæg. Johnstad og Ole talte, og jeg foreslog en skål for Ellen ${ }^{15}$ og Bent. ${ }^{16}$ Det blev, forholdene taget $\mathrm{i}$ betragtning en god fødselsdag.

10.3. Wassermann ${ }^{17}$ afsatte idag Ole som barakformand, så må vi se, hvem germanerne vil have som afløser. Jeg er på tale, men finder det mere rimeligt, at $\mathrm{Hugo}^{18}$ rykker op, og heri er barakken enig.

11.3. Wassermann har anerkendt Hugo som formand, og jeg blev næstformand, så nu bytter Ole og jeg logi, og jeg rykker ind på formandskontoret. Her er en masse at se til, men så går tiden godt. Vi har en fordel i ledelsen. Vi får flere oplysninger om mangt og meget ved "sognerådsmøderne“. Noget skal vi lade sive ud, og andet er kun noget, vi skal gemme for os selv. Men det er ikke rygter. ${ }^{19}$

13.3. Begynder dagen med løbetur på $2 \mathrm{~km}$, og så en kold bruse. Er så småt ved at blive solbrændt. Spiller skak med Jørgen hver formiddag, når der kan blive ro til det, for ikke sjældent afbrydes det af "alumnerne", der skal have svar og hjælp til deres problemer.

Først når det er blevet sengetid og tyskerne har låst barakken af for natten, bliver her ro. Jeg sidder med vinduerne ảbne. Og gennem skoddernes små huller kan jeg se det er stjerneklart, og jeg kan følge projektørenes fejende lys fra vagttårnene. De fløjtende toner i luften fortæller, at der er forårstræk. Himlens frie fugle bryder sig en døjt om krig og pigtrådshegn. De er på vej mod ynglepladserne mod nord.

28.3. Termometeret har i de sidste dage vist 15 grader. Der slikkes solskin langs barakkerne i korte bukser og nøgen overkrop. Meisterne giver ondt af sig og prøver at jage fangerne til arbejdet, men når de er vak, bliver der atter taget solbad. Vi er nu over 3.000 i lejren. Jeg er blevet ret brun og har også tabt en del af de pund, jeg havde lagt mig til som spisegeneral, hvor jeg havde let adgang til godbidder.

Et par sorte dage har der været i den lyse forårsstemning, et par små 
transporter er gået mod syd. Den ene gang 8 kendte navne, åbenbart en slags gidseltransport. Peter Marcussen ${ }^{20}$ og Johnstad måtte med.

Og så har der været både brev og pakke hjemmefra. De er i fuld gang med forårsarbejdet. Aviserne beretter om mord, bombardementer, sabotage og henrettelser og om knaphed på visse levnedsmidler. Rent materielt begynder krigen at kunne mærkes i Danmarks byer. Flygtningene fra Østpreussen strømmer ind $\mathrm{i}$ landet. På fronten raser kampene, men de allierede gårstadig frem.

Jeg har fået sendt en hilsen til Tom. Af en eller anden mystisk grund må vi ikke have penge på os, men vi må gerne sende dem hjem. Jeg sendte $10 \mathrm{kr}$. og benyttede så bagsiden af postanvisningen til at skrive, at alt stod vel til. Den fidus har mange benyttet sig af, men ellers har vi beholdt vore kontanter, der er brug for dem på forskellig vis. Jeg var ovre i den danske forvaltning i et legalt ærinde og fik så en pose med $10.000 \mathrm{kr}$. illegalt, som jeg skulle bringe ind $\mathrm{i}$ lejren. Jeg drog et lettelsens suk, da jeg kom gennem tårnet uden en alt for grundig visitation. Det ville nok have været svært at få germanerne til at tro, at jeg havde vundet de $10.000 \mathrm{i}$ kortspil.

De mange penge bliver anvendt til våbenkøb hos det tyske vagtmandskab. Digmann er begyndt at forberede afslutningen. I hver barak er vi en gruppe, fortrinsvis folk, der har været soldater og som kan bruge et våben. Vi skal i en given situation være parate til en indsats. Knaphed på tobak i lejren. Det giver utilfredse fanger, der gnaver på hinanden, og der er endnu 14 dage til tobaksuddeling.

Tankerne går meget til hjemmet. Nørmark ligger ved alfarvej, det er i disse urolige tider et minus. Bøge ${ }^{21}$ er ankommet til lejren. Han hedder ganske vist noget andet. Det vil blive spændende at høre om hans oplevelser.

4.4. Tiden farer afsted. Det varme milde vejr er afløst af rigtig aprilsvejr med haglbyger og mellem dem tindrende sol. Lejren vokser og vokser. Her er meget at gøre på formandskontoret med spisehold, arbejdshold og flytninger. Jeg har ikke megen tid til at gå mine ture. Ro er der heller ikke, hverken til læsning eller skak.

Der spekuleres og tales meget om krigens afslutning. Frontberetningerne er gode, men forudsige afslutningen er og bliver gæt. Jeg ønsker, men tror ikke jeg kan komme hjem på vor 5 års bryllupsdag. Det ville ellers være herligt. Jeg savner de tre rædsomt. Derimod er det mærkeligt, at de praktiske ting på gården er trængt $\mathrm{i}$ baggrunden. Jeg har erkendt, at jeg intet kan gøre.

Enkelte bliver løsladt, men desværre bliver nogle også sendt til København, og det er sjaldent for det gode.

Til mit job hører også, at jeg skal censurere breve. Vi i den danske 
lejrledelse skal stoppe breve, som vi ved tyskerne vil stoppe, og bliver de stoppet der, er det et afsendt brev. Vi har mulighed for at moderere udtalelser, som ville have forhindret at de pårørende havde modtaget en hilsen. Brevet må skrives om, så det kan gå igennem. Et brev idag var skrevet med lydskrift på jysk. Et andet brev idag havde vendingen: "Det er dog satans, som det her trækker ud, så I må hellere holde konfirmation." Et havde i samme sætning slået det åndelige og timelige sammen. Det lød: Bed for os, for bøn trænger vi hårdt til, og så at få den lille kvie dækket. “ Imorgen har jeg været indespærret i 7 måneder, syv lange måneder, blot jeg ikke får den ottende med. Hvor skal det blive dejligt at komme hjem. Idag stor overflyvning. Nu kommer englændere og amerikanere ikke kun om natten. Vi talte en luftarmada med flere hundrede maskiner på den blå himmel. Ugenert flyver de.

9.4. Så har Danmark været besat i 5 år. Det ville have været vidunderligt, om vi var blevet frie på denne dag, der stedse vil stå $i$ ens erindring som en skammens og sorgens dag.

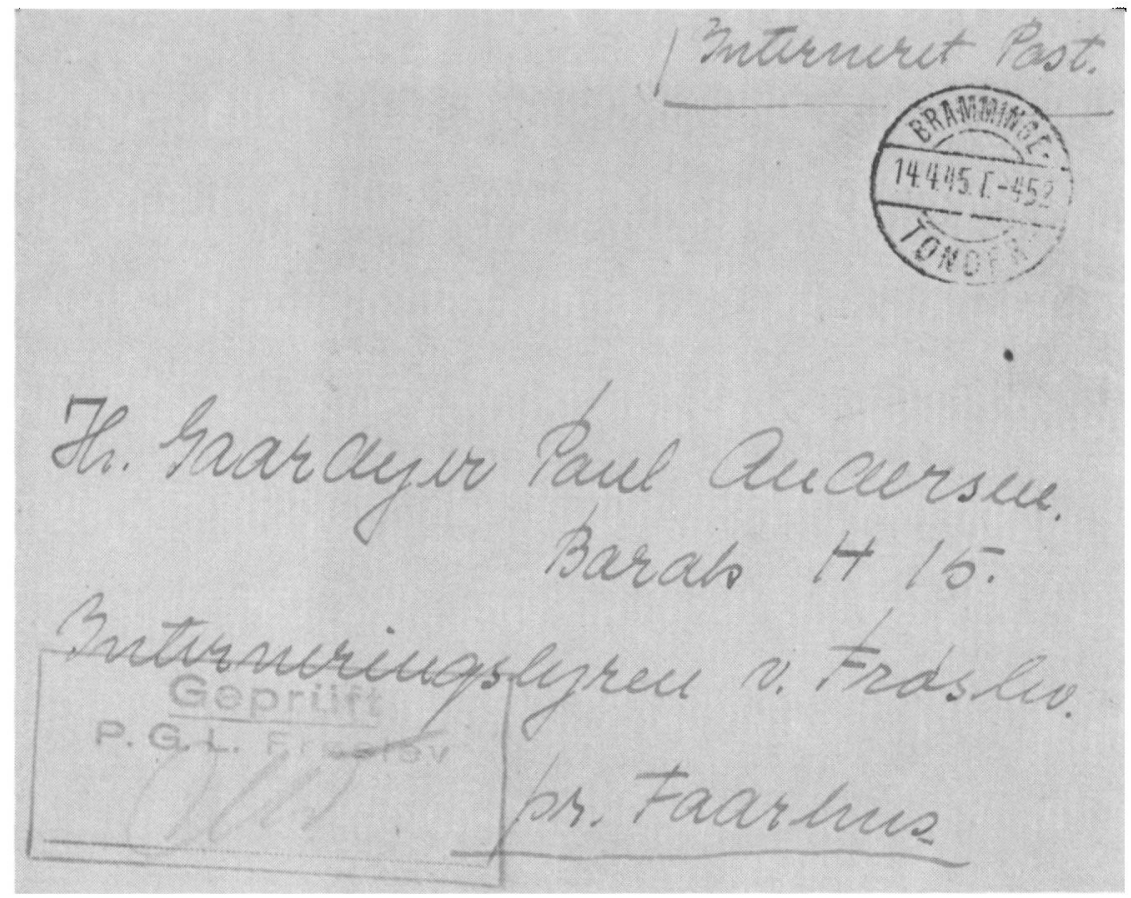

Kuvert til et af de karkomne breve på 20 linjer afsendt 14.4.45. I nederste venstre hjarne er der stemplet "geprüftu med ulaselig signatur. 
På bordet foran mig har jeg tre hyldepinde i vand, de er ved at få grønne skud, en beskeden forårsbebuder, her hvor det eneste grønne er tyskernes uniformer og granerne rundt om os. Ellers lyng og sand. Nu det er tørt, hvirvles sandet op, der er konstant en støvsky over lejren. Vi er mange indbyggere nu, ialt $4.500 \mathrm{i}$ lejren, så plads er der ikke meget af. Her ca. $8 \mathrm{~m}^{2} \mathrm{pr}$. individ, men det gør ikke noget, vi er mange, når det er dem fra Tyskland, der kommer hjem. Her er om ikke for meget husrum, så i al fald hjerterum til alle fra KZ-lejrene.

Havde idag lov at skrive hjem, og det er rart at kunne meddele, at alt står vel til. Nu er markerne ved at grønnes. Gid det må blive et godt år. Vi vil få brug for lidt medvind. Taler med mange fra Neuengamme. Holger og Erik skulle have det hæderligt. Det er rart at høre. Forfærdeligt, ja umenneskeligt har opholdet i lejrene været. Ubegribeligt, at nogen overhovedet har overlevet sult, prygl og strabadserne. Ufattelig, den ondskab SS har udvist mod fangerne. Det er mørk, mørk middelalder.

Jeg forsøger mig som billedskærer med et hjerte til Tom. Mange af kammeraterne er fortrinlige billedskærere. Der fremstilles hjerter, elefanter, papirknive og Frø-sleve, en ske med en frø på skaftet. Nu har vi lus i barakken, det er hyggeligt. Jeg håber inderligt at undgå det.

Nordschleswigsche Zeitung er opmuntrende læsning. Redaktionen vrider sig på mangfoldige måder. Den kan næppe selv tro på det, den skriver, at sejren er lige om hjørnet. I al fald ikke en tysk sejr. Har opgivet at komme hjem til vor 5 års bryllupsdag d. 18.4., men håber nu på, at det må ske til maj. Der er efterhånden ikke meget tilbage af Tyskland, både fra øst og vest rykkes der frem.

18.4. Jørgen er blevet løsladt. Jeg vil savne mine skakpartier med ham og de mange gode samtaler, vi havde. Og idag blev så Hugo løsladt. Han blev helt ellevild af glæde, da han fik besked herom. Han har også næsten et års indespærring bag sig. Hans knevren og rod vil jeg savne. Jeg har næsten ingen stemme i disse dage, og det er upraktisk i mit job. Alumnerne griner, når jeg hvisker mine ordrer. Bryllupsdagen snakkede jeg med $\mathrm{Magle}^{22} \mathrm{om}$, han viede os for 5 år siden i Kristkirken i Tønder, da tænkte man ikke, at denne dag skulle fejres under disse omstændigheder.

Og så er jeg idag nået til "ærens tinde“. Jeg er blevet barakformand i H.15. Det er et krigsstærkt kompagni, jeg har at holde styr på, der er tæt ved 300 mand $\mathrm{i}$ barakken. Jeg har indstillet Paul ${ }^{23}$ til næstformand, og håber, at Wassermann vil godtage ham.

Fik visit af Niels. Han havde organiseret to $æ g$, så vi rørte os en æggesnaps, delte et æble og citerede digte af Holstein. Og så kom der brev fra Tom, der 
fortalte om udsprungne bøgegrene, grønne marker. Køerne er på græs, og storken byggede på sin rede på hestestalden. Det var væmmeligt dejligt. Jeg vil hjem.

21.4. Nu forlyder det, at vi kan vente vore sidste kammerater hjem fra de tyske lejre. Paul blev næstformand og er nu flyttet herind, og så forskellige vi er, kommer vi vældig godt ud af det sammen. Han er effektiv og beslutsom. Han er også med $i$ kampgruppen $i$ denne barak, og vi har nu vore våben parat i væggen, hvis de skulle blive nødvendige. Vi spekulerer en del på, hvordan afslutningen vil forme sig. Mange af politisoldaterne ønsker lige så stærkt som vi at få en ende på krigen. De spiser af den hule hånd og er parate til at bistå os, hvis SS skulle gå over gevind.

Kl. 1 nat blev vi vakket. De hvide busser rullede ind, og selv om vi her $i$ H.15 har topbelægning, måtte vi finde udvej for yderligere plads til 50 mand i barakken, men vi gjorde det gerne. På alle stuer blev der taget vel mod kammeraterne. Det er dejligt at se dem igen efter de mange måneder. Mange er stærkt mærkede af opholdet. De var umådelig sorte og meget trætte, men uendelig glade. Det var en stor og dejlig oplevelse at kunne byde velkommen hjem. Godt, at så mange trods alt har klaret sig. Men vi hører også om tabet af mange gode venner.

22.4. En forvirret dag. Flytning ind og ud af barakken. Ustandselig kom der mennesker herind på formandskontoret, sagde goddag, bragte hilsener. Stemningen i lejren er fantastisk. Glæden og optimismen er overvældende. Nu kan det ikke vare længe før der er fred. Talte med Holger. Han vidste ikke med sikkerhed noget om Erik, kun at han var blevet sendt på udkommando.

Paul og jeg tog Viggo herind som logerende, men så er her også meget småt med pladsen, men det er der i alle stuer. Viggo er meget forandret, og det er rystende ting han beretter om. Man vægrer sig næsten ved at tro, hvad man hører, men vidnedsbyrdene fra andre er samstemmende.

En stor oplevelse idag var Bernadottes besøg. Pludselig rygtedes det, han var $i$ lejren for at inspicere den. Mens han var inde i sygebarakken, samledes $i$ tusindvis af fanger på appelpladsen, hvor vi ventede for at se den mand, der ved sin indsats havde reddet så mange danske og norske fanger fra den visse død. Tyskerne vidste ikke rigtig, hvad de skulle gøre ved denne sammenstimlen. Og så kom Bernadotte ud. Stod på trappen og så ud over alle de mange fanger. En eller flere begyndte at fløjte "Du gamla, Du fria» og så steg tonerne, nogle nynnede, de fleste fløjtede den svenske nationalsang til ære for den ranke greve. Det var et betagende ojeblik, og det gjorde indtryk på Bernadotte, han rettede sig op og gjorde honnør, mens vi fløjtede. Nikkede til 
tak og fulgt af den forvirrede Storbandit gik Bernadotte gennem rækken af fanger.

23.4. Nu forlyder det, at lejren skal evakueres til Sverige. Fjernskriveren tikker ovre i Geschäftszimmer. Navn efter navn på dem, der skal afsted. Uofficielt har jeg fået at vide, at mit navn er på listen. Det er jeg ked af. Jeg vil ikke til Sverige. I bedste fald vil jeg så ikke være i Danmark før 24 timer efter krigsafslutningen. Jeg vil hjem. Transporten siges at skulle afgå imorgen.

24.4. Transporten til Sverige blev udsat 24 timer. Jeg skulle i løbet af dagen få endelig besked, om jeg skal med, og sidst på eftermiddagen fik jeg besked. Imorgen er det afgang herfra. Vi har $i$ aften holdt en lille afskedsfest her $\mathrm{i}$ formandskontoret. Niels, Viggo, Paul og jeg nød nogle af de gode sager, de hjemvendte havde medbragt. Amerikanske cigaretter, kaffe og chocholade og rare kiks med marmelade. Det var et helt festmåltid, og vi snakkede til kl. blev 2. Det passer mig ikke at skulle herfra og skilles fra dem, jeg har delt ondt og godt med i næsten 8 måneder. Jeg er spændt på, hvad morgendagen bringer. Får jeg en chance, så vil jeg prøve at hoppe af.

25.4. Kl. 9.30 kom listen over dem, der skulle evakueres fra barak H.15. Vi er 53 her fra barakken, der fik besked om at møde ved tåmet kl. 12. Her fik vi vore konfiskerede ting udleveret og blev kl. 15 puttet $\mathrm{i}$ rutebiler og under militærbevogtning kørt til Padborg station. Mærkeligt at køre ud fra lejren, hvor vi nu gennem mange måneder kun havde set hede og granskov og gult sand. $\mathrm{Nu}$ kom vi ud $\mathrm{i}$ et forårslandskab med grønne marker, buske og løvtræer fuldt udsprungne og frugttræer med bristefærdige knopper.

På Padborg station blev vi ført til det holdende tog. Der var tyskere alle vegne med maskinpistoler. En ved hver dør. Vi hang ud af vinduerne, talte med folk. Afspærringen på selve perronen var ikke særlig streng, og vi kunne købe aviser. Visiteringen $i$ lejren havde været ret lemfældig, og mens vi holdt fik jeg pakket min dagbog og andre småting $i$ et brev til Tom og fik det afleveret til en mand på perronen, der lovede at sende det. Jeg sonderede situationen lidt, og selv om jeg havde tænkt først at springe af på et senere tidspunkt, fandt jeg ud af, at jeg ligesågodt kunne gøre det her. Jeg gav en i kupeen besked om at sende min kuffert. Tog en avis $i$ hånden, og mens vagten ved vogndøren et øjeblik vendte ryggen til, trådte jeg ned på perronen, hvor jeg ivrigt fordybet $i$ avisen gik hen mod udgangen, gennem tunnellen og ud fra stationen.

Lige uden for stod to tyske MP. Jeg syntes, de måtte kunne se, at jeg var en undvegen häftling, men de antastede mig ikke, så jeg gik videre hen ad gaden $\mathrm{i}$ 
et roligt tempo, selv om jeg havde mest lyst til at lobe, og uden at se mig tilbage. Måneders indespærring havde ellers gjort, at man altid var vant til et sideblik over skulderen for at have et øje med, hvor den nærmeste germaner var.

Men som jeg kom længere væk fra stationen, blev jeg roligere og begyndte at fatte, at jeg var fri. Fri. Nogen plan for, hvad jeg ville, havde jeg egentlig ikke, men begyndte at gå mod Bov og kunne nu rigtig nyde foråret omkring mig. Udsigten ned mod Kruså med de stærkt svungne bakker og skovene ved Kobbermøllen var et dejligt syn. Da jeg kom til dr. Lorenzens hus, fik jeg den ide, at han måske kunne køre mig lidt længere væk. Jeg havde hilst på ham $\mathrm{i}$ lejren. Jeg gik ind i lægeboligen, hvor jeg traf fru Lorenzen, der oplyste at lægen ikke var hjemme og ikke ventedes foreløbig. Jeg gav mig så til kende, refererede til hendes broder, Niels Lund og min svoger, der havde været vikar hos dr. Lorenzen, og spurgte, om jeg ikke kunne låne en cykel. Fru Lorenzen virkede lidt adspredt, men jeg kunne da godt låne hendes cykel, og så fortalte hun mig, at manden om formiddagen var afhentet af Gestapo og var blevet anbragt i det tog, som jeg var hoppet af, og hvor berørt af situationen hun var, kom frem i hendes næste bemærkning: "Nu er De vel ikke stikker?“ Efter at have beroliget hende $i$ så henseende fik jeg cyklen og kørte min vej. Stadig vidste jeg ikke rigtig, hvad jeg ville. Helt hjem turde jeg ikke tage, men bestemte mig til at køre mod vest. Hvor banen skærer Tønder landevej, kom en tysk patrulje frem fra ledvogterhuset, da jeg var ca. $50 \mathrm{~m}$ derfra. Nu er du allerede efterlyst, tænkte jeg. Vende om ville imidlertid se helt forkert ud, så jeg bestemte mig til at forsøge at bluffe mig forbi. Jeg blev standset og skulle forevise legitimationskort. Det havde vi heldigvis fået udleveret, da vi forlod lejren. Jeg havde allerede brygget en historie sammen om, at jeg havde været på handel, men det blev ikke nødvendigt med forklaringer. Efter at have set kortet, hed det: Weiterfahren, og glad var jeg.

Jeg cyklede så videre, og da jeg kørte gennem Jyndevad, blev jeg overhalet af en cyklist, som jeg kendte. Det var Frederik Heick ${ }^{24}$ fra forsø gsgå rden. Jeg fortalte ham, at jeg var hoppet af toget, og spurgte, om han ville huse mig. Uden betænkning svarede han ja. Vi aftalte så på vejen til forsøgsgården, at jeg skulle være ingeniør Anders Poulsen, der skulle arbejde ved det vandingssystem, der var ved at blive installeret. Ingeborg Heick tog ligeså gæstfrit imod mig, som Frederik havde gjort, og jeg blev præsenteret for gårdens karle, og de blev gjort bekendt med, at jeg var flygtet, og det aftaltes, at i tilfælde af, der om dagen kom tyskere til gården, så skulle der råbes: "Tyren er lø̋s", og så måtte jeg se at finde et skjulested.

Men foreløbig var der fred og ingen fare. Jeg fik et dejligt værelse. Talte $i$ telefon med Tom uden at meddele, hvor jeg var, og efter at vi havde hørt de 
sidste nyheder, fik jeg bad, kom i en rigtig seng og sov 10 timer i træk de uskyldiges søvn ovenpå denne dejlige dag.

26.4. Frederik Heick og jeg cyklede om formiddagen over til Jørgen Tingleff $i$ Lund. I sin egenskab af sognerådsformand kunne han udstyre mig med et nyt identitetskort, hvor jeg fik navneforandring. Nogle rationeringsmærker fik jeg også. Resten af dagen gik med gravearbejde i marken, og jeg nød det. Heicks skulle væk om aftenen. Det var St. Bededagsaften, og de havde så inviteret Tom til at komme på besøg. Hun kom cyklende fra Nørmark til aftensmad, og så mødtes vi atter efter 8 måneders adskillelse.

5.5. St. Bededag var Tom atter taget tilbage til Nørmark, og i de sidste dage inden kapitulationen kunne alle se, at nu var det næsten kun spørgsmål om timer. 1. maj kom meddelelsen om, at Hitler var faldet, og radioen fra London lyttede vi ustandselig til. Ville krigen nå Danmark, eller ville den stoppe forinden?

Der var konstant brummen i luften af allierede fly, og i de stille aftentimer hørte vi ikke sjaldent bombebrag mod syd.

Og så fredag den 4. maj, da vi atter sad ved radioen, kom den lykkelige melding fra London, at alle tyske tropper i Holsten, Slesvig og Danmark kapitulerede, og at alle krigshandlinger skulle standse næste morgen kl. 8 .

Jeg bestemte mig til straks at tage hjem til Nørmark, og efter at have takket mine værter for husly, cyklede jeg mod Tønder. Det var blevet mørkt. Lyskastere fejede over himlen, og mod syd kunne jeg høre skydning. Af og til kom en bil imod mig, og da det sandsynligvis var en tysk militærbil, gik jeg i dækning, til den var passeret. Endelig nåede jeg Tønder, hvor der ikke længere var mørkelægning, og fra husene lød glade stemmer. De tyske huse lå tavse og mørke. Jeg kørte om til dommerboligen for at høre nyt. Jeg havde efter de planer, der var lagt af politi og militær mødeordre til den situation, der nu forelå. Hos Stegmanns ${ }^{25}$ var også Kiørboes ${ }^{26}$, og jeg blev budt velkommen, og vi drak en skål på befrielsen.

Og nu fik jeg at vide, at der var noget, der hed en regionsledelse, og jeg roligt kunne tage hjem. Jeg nåede til Nørmark mellem 1 og 2 nat. Gensynet var vidunderligt. På 8 månedersdagen for min arrestation var jeg atter hjemme, samlet med mine kære.

Om morgenen samledes vi med karle og piger $\mathrm{i}$ haven for at hejse Dannebrog. Jeg havde en klump i halsen, da flaget gled til tops. Danmark var frit. 


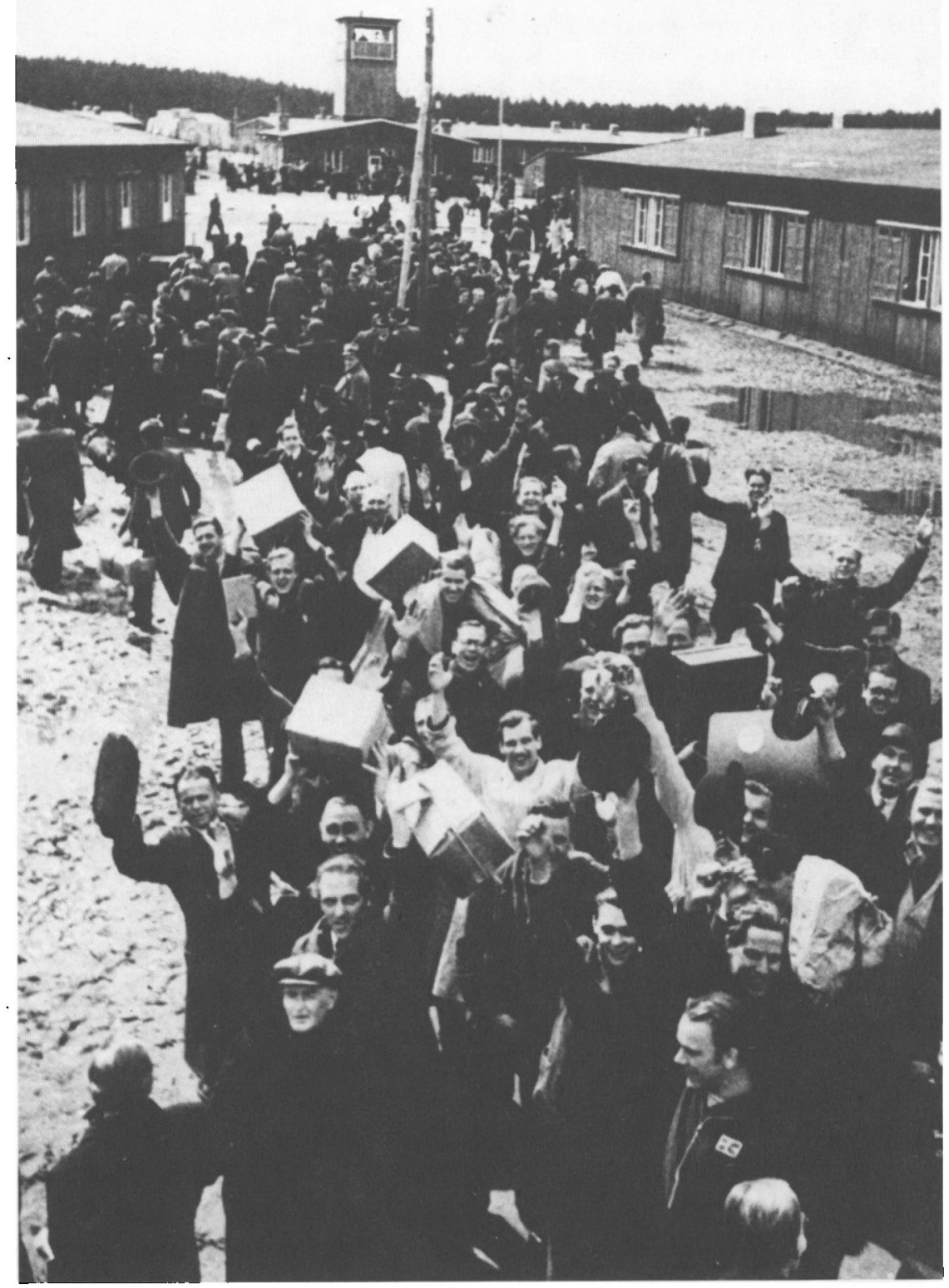

Glade fanger på vej ud til friheden d. 5. maj 1945. (Museet for Danmarks Frihedskamp 1940-45). 


\section{NOTER}

1. Dagbogskriverens kone, kaldet Tom.

2. Kaptajn Otto Olsen, senere oberst. Regionsleder. Åbenrå.

3. Kaptajn Carl G. Bartholdy, senere oberstløjtnant. Deltog i kampen ved Bredevad 9.4.1940. Regionsleder. Ábenrá.

4. Bernsen. Lokalredaktør af Hejmdal. Tønder.

5. Lektor Aage Rosenkjær. Tønder Statsskole. Døde 18.11.1944 i KZlejren Schwesing ved Husum.

6. Strandpromenaden eller Sandpromenaden kaldtes det sandede område langs lejrens pigtrådshegn.

7. Gustav Grüner, senere oberst, kammerherre, chef for Livgarden.

8. Johnstad Møller. Senere general. Chef for Hjemmeværnet.

9. Holger Petersen. Isenkræmmer $i$ Tender.

10. Erik Svendsen. Bankassistent i Tønder. Kom til Neuengamme. Forsvandt på udkommando i dagene op mod kapitulationen.

11. Niels Nørlund. Senere chefredaktør, Berlingske Tidende.

12. Jargen Boisen Træden. Student. Senere prakt. læge i Osted.

13. Gøga Balslev. Børnehavelærerinde i Tønder. Senere gift med Franz Wingender, Flensborg.

14. Digtet er skrevet af den norske digter Gunnar Reis Andersen.

15-16. Carl Bartholdys kone og son.

17. Wassermann. Tysk næstkommanderende i Frøslevlejren.

18. Hugo Kielgast. Salgschef i Århus.

19. Der fandtes en illegal radio i lejren. Nyheder herfra blev givet til den danske lejrledelse.

20. Lærer P. Marcussen. Formand for Det Unge Grænseværn.

21. Ingeniør J. M. Bøge, Tønder. Leder af modstandsarbejdet på Tønder-egnen til december 1944. Flygtet til Sverige. Derfra til England og tilbage til Danmark. Løjtnant i den engelske hær.

22. Pastor H. Magle. Sognepræst i Tønder.

23. Paul Meisen. Direktør i A/S Holger Petersen, København.

24. Frederik Heick. Leder af Statens forsøgsstation. Jyndevad. Senere formand for Det danske Hedeselskab.

25. H. H. Stegmann. Dommer i Tønder.

26. Ernst Kiørboe. Lektor ved Tonder Statsskole. 